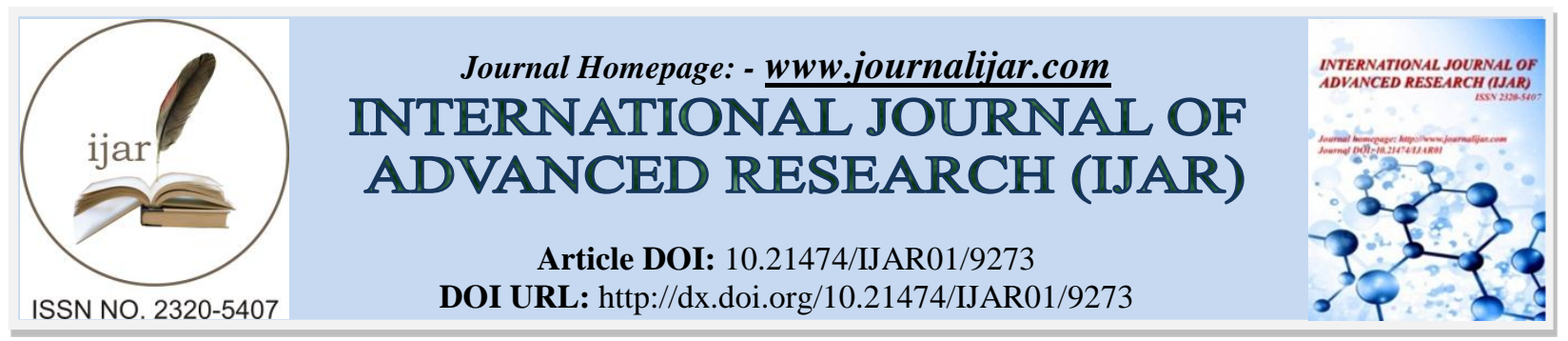

RESEARCH ARTICLE

\title{
MELISSOPALYNOLOGY AND CLIMATIC VARIATION: CASE OF HONEY ATTRIBUTED TO EUPHORBIA RESINIFERA, REGION OF AZILAL (MOROCCO).
}

\author{
Abderrahim Ihitassen ${ }^{1,2}$, Younes Belrhazi ${ }^{1}$, Ismail Bettar ${ }^{1}$, Fouad Msanda ${ }^{2}$. \\ 1. Laboratory of Applied Geology and Geo-environment, Faculty of Sciences, Ibn Zohr University, Agadir \\ Morocco. \\ 2. Laboratory of Biotechnologies and Valorization of Natural Resources, Faculty of Sciences, Ibn Zohr University, \\ Agadir Morocco.
}

\section{Manuscript Info}

.........................

Manuscript History

Received: 12 April 2019

Final Accepted: 14 May 2019

Published: June 2019

Key words:-

Melissopalynology, honey, Euphorbia resinifera, flowering, climate, region of Azilal, Morocco.

\section{Abstract}

This work is an example of the use of honey in the study of the impact of global warming on nectar production and the relationship between plants and pollinators. It is the result of the melissopalynological analysis of 42 honey samples attributed to Euphorbia resinifera Berg, from the region of Azilal (Morocco). Quantitative analysis showed that these honeys are mostly poor in botanical elements. Although beehives were established during the flowering period of Euphorbia resinifera, in areas dominated by it, only $16.7 \%$ of honeys harvested showed the monofloral character associated with the species. The others are multifloral or honeydew produced mainly by the holm oak (Quercus ilex). The qualitative analysis of the honeys showed the presence of 55 botanical taxa belonging to 24 families. Pollen from herbaceous species is better represented than pollen from shrubs and trees. Entomophiles are dominant. The evolution of the pollen percentages of E. resinifera in the pollen spectrum has shown that the precocity of its flowering related to the increase of the temperature and the diminution of the precipitations has negatively influenced its nectar production, its attraction for bees, and its contribution to the elaboration of honey.

Copy Right, IJAR, 2019,. All rights reserved.

\section{Introduction:-}

Morocco has a remarkable floristic diversity, with more than 4500 species of vascular plants (Anonymous, 2014) of which about a quarter is endemic. This flora is at the origin of different varieties of monofloral and multifloral honeys with a good national and international reputation. Three of these honeys are derived from cactiform and succulent endemic species of the genus Euphorbia (Euphorbiaceae): Euphorbia officinarum L. subsp. Echinus (Hooker fil. \& Cosson) Vindt, Euphorbia officinarum L. subsp. Officinarum (Hooker fil. \& Cosson) Vindt and $E$. resinifera Berg.

These honeys were the subject of many scientific studies (Naman et al., 2005; Aazza et al., 2014; Crousilles, 2014; Terrab et al., 2014 ; Bettar et al., 2015; Bouhlali et al., 2016 ; Chakir et al., 2016 ; Petretto et al., 2017 ; Moujanni et al., 2017). For honeys of E. resinifera, although they have benefited from the Protected Geographical Indication "PGI" (Anonymous, 2012), no palynological study has been undertaken. Thus, the goal of this work is to fill this gap.

Corresponding Author:-Abderrahim Ihitassen.

Address:-Laboratory of Applied Geology and Geo-environment, Faculty of Sciences, Ibn Zohr 
Euphorbia resinifera "zekkoum in the Moroccan dialect", is a succulent plant with erect stems, very tight little ramous, up to $1 \mathrm{~m}$ high and forming tufts of 0.5 to $2 \mathrm{~m}$ in diameter. The glabrous branches are tetragonal, rarely trigonal, with very vulnerable, conspicuous spines (Fennane et $a l, 2014$ ). The inflorescence is a simple solitary cyme, with yellow cyathia, developing on the edges, at the upper end of the stems. The flowering period depends on the weather conditions. The fruits are tricoic capsules, with explosive dehiscence. The different parts of the plant contain milky latex, the resiniferatoxin, which causes irritation in contact with the skin.

The plant is confined essentially to arid, often carbonated rocky piedmonts and low mountains of the Atlas of BeniMellal and Demnate (Benabid, 2000) where the coverage may exceed $60 \%$. The main taxa, both woody and shrubby, associated with it are Acacia gummifera, Ceratonia siliqua, Chamaerops humilis, Olea europaea, Pistacia lentiscus, Rhus pentaphylia, Tetraclinis articulata, and Ziziphus lotus. Typically Mediterranean genera such as Asphodelus, Ballota, Biscutella, Cistus, Ferula, Hippocrepis, Lavandula and Ruta are well represented (White, 1983). For its melliferous potential, Euphorbia resinifera is a nectariferous plant that produces a rare, highly sought after honey for its medicinal and economic value.

The present study was carried out during 2014 and 2015 in order to specify the palynological characteristics of monofloral honey of Euphorbia resinifera, an endemic species of Morocco which dominates the flora of certain areas of the Region of Azilal (Morocco).

\section{Material and methods:-}

\section{Sampling areas:}

In order to have a good representation of the area of the Euphorbia, we chose 5 areas representing different ecogeographical situations (Fig. 1):

- Ait Attab (840 m), a forest area consisting mainly of holm oak (Quercus ilex), cedar and of two juniper species (Juniperus oxycedrus and J. phoenicia). In this location, Euphorbia resinifera spreads over large areas along the forest;

- Foum Jamâa $(890 \mathrm{~m})$, located in a generally forest environment where Euphorbia resinifera is associated with cedar (Tetraclinis articulata) and red juniper (Juniperus phoenicea) and where cereal crops, almond and olive tree cultivation are dispersed on small fields at the edge of the forests;

- Tanant $(940 \mathrm{~m})$, the Euphorbia colonizes an important area of a forest consisting mainly of cedar, red juniper and of holm oak;

- Azilal $(1300 \mathrm{~m})$, a mid-mountain area where oak is associated with cedar, red juniper, lentisk (Pistacia lentiscus) and cistus (Cistus villosus); Euphorbia occupies the slopes;

- Ait Mhamed (2000 m), an area of high mountains where the Euphorbia occupies the slopes dominated by holm oak.

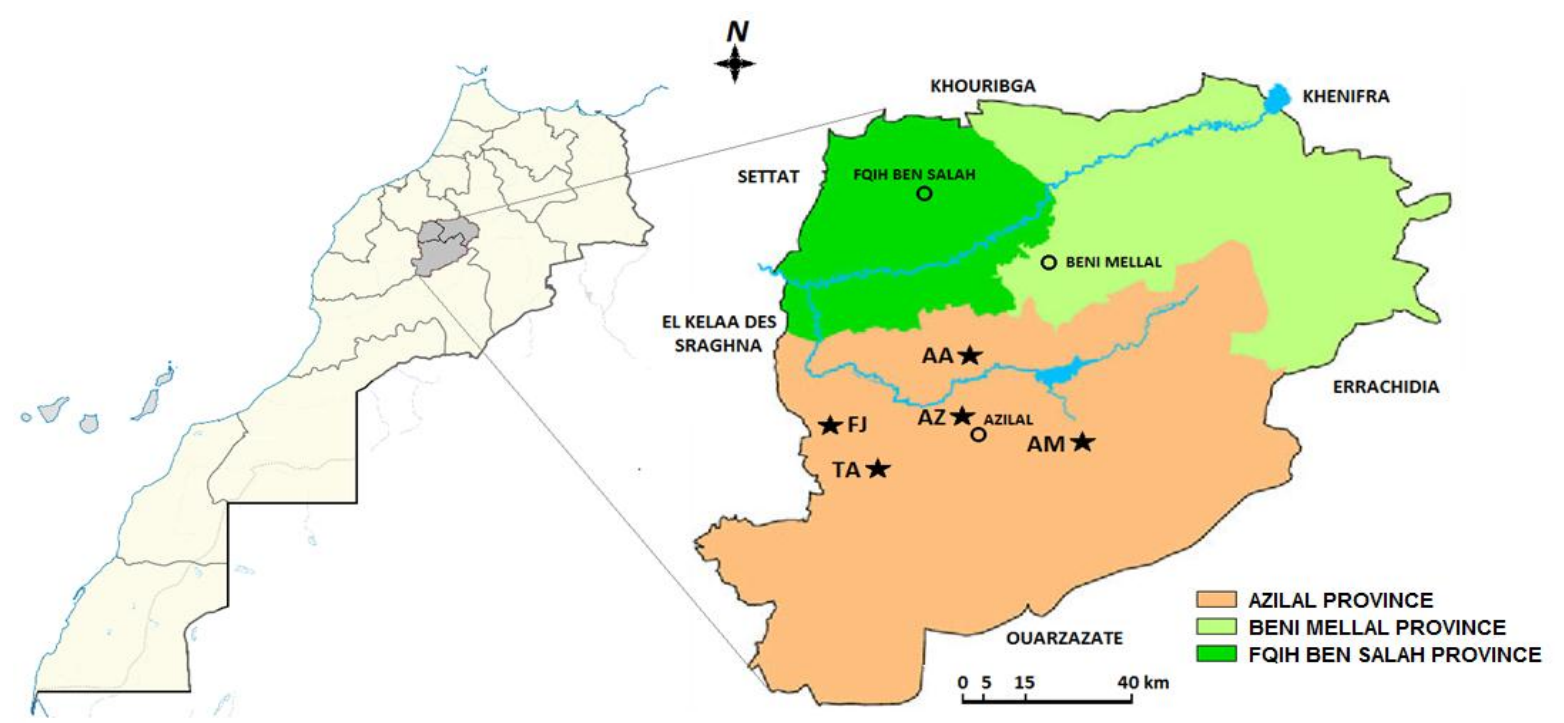

Fig. 1: Localization of studied areas: AA: Ait Attab; AM: Ait Mhamed ; AZ: Azilal ; FJ: Foum Jemaa ; TA: Tanant. 


\section{Analysis methods:}

Hives were planted in sites dominated by E. resinifera, at the beginning of its flowering, from mid-April in the lower elevation areas (Ait Attab, Foum Jemâa and Tanant) and for the second week of May in the highest sectors (Azilal and Ait Mhamed). We also established a reference collection of pollen grains from the flora of the region during the study period. The samples were collected at the end of the floraison period of Euphorbia resinifera in July for the two years of study.

The melissopalynological analyzes, quantitative and qualitative, were performed according to the method described by Louveaux et al. (1978), reviewed by Ohe et al. (2004) and summarized in Terrab et al. (2014). Analyzes are done on a 10 grams of honey basis. The determination of the different palynomorphs, their counting and their photographs were done under the Leitz laborlux S microscope.

The identification of pollen grains is based on their morphological criteria. For their botanical attribution, we used our reference collection and the Atlas of literature (Moore et al., 1991; Reille, 1992; Valdés et al., 1987). Some taxa are determined up to the species or genus. When a set of genera of the same family coexisted during the foraging period and have the same pollen type, we assigned the pollen with the same characteristics to the most dominant genus with the indication "type" which follows the name of the genre (i.e: Lotus Type).

For the classification of honeys, we followed the approach proposed by the International Commission for Bee Botany (ICBB) (Louveaux et al., 1978) based on the percentages of the various elements of the melissopalynological residue (pollen grains and elements of honeydew). For each sample, we counted and determined a minimum of 1000 pollen grains which we grouped according to the 4 frequency classes defined by Louveaux et al., $(1970,1978)$ designating as :

1. Dominant or predominant pollen ( $\mathrm{n}>45 \%$ of a specific type of pollen);

2. Accompanying or secondary pollen $(15 \%<\mathrm{n}<45 \%)$;

3. Minor important or tertiary pollen $(3 \%<\mathrm{n}<15 \%)$;

4. Minor or rare pollen $(\mathrm{n}<3 \%)$.

For the botanical attribution, we used the measurement of electrical conductivity (EC), an important parameter according to the International Honey Commission (IHC) (Bogdanov et al., 1997, 2004), to differentiate flower honeys from those of honeydew (EC>800 $\mu \mathrm{S} / \mathrm{cm}$ for honeydew's honey and $\mathrm{EC}<800 \mu \mathrm{S} / \mathrm{cm}$ for nectar's honey). The proportions of the different pollen grains of nectariferous taxa allowed us to decide between monofloral and multifloral honeys.

\section{Results:-}

The harvested honeys showed the following sensory characteristics: amber colored with a sweet smell and a persistent taste sticking to the throat after swallowing. These characteristics allow beekeepers, resellers and consumers to consider this type of honey as Euphorbia monofloral.

The results of the quantitative analysis (Table 1) show that the number of pollen grains per $10 \mathrm{~g}$ of honey varies between 3133 (sample 19) and 1190667 (sample 31). According to Maurizio classification (1979), 50\% of the collected honey ( 21 samples) are poor in pollen and belong to class I, 47.6\% (20 samples) have an average content (class II and III) and only one sample is very rich (class V). The honeydew indicator elements (HDIE) are present in all honeys analyzed with a number varying from 448 (sample 17) to 924667 (sample 31). Their ratio to nectarine pollen grains (HDE / NPn) or honeydew index (HDI) is between 0.02 and 3.55.

The qualitative analysis (Table 2) reveals the presence of 55 pollen types belonging to 24 families. The pollens of herbaceous species are better represented than those of shrubs and trees. Entomophilous species are dominant. 80\% of the taxa encountered are nectariferous and $20 \%$ belong to anemophiles or to entomophiles poor in nectar or nectarless (Fig. 2). The number of pollen forms per sample varies from 5 (sample 1) to 22 (sample 35) with an average value of 13 . 
Table 1: Results of the quantitative analysis of the 42 honeys studied.

NBE: number of botanical elements; NPF: number of pollen forms; HDI: honeydew index; EC: Electrical conductivity; $\boldsymbol{F H}$ : Flower's honey.

\begin{tabular}{|c|c|c|c|c|c|c|c|c|}
\hline Sites & Date & Samples & NBE & NPF & HDI & Class & Type & EC $(\mu \mathrm{S} / \mathrm{cm})$ \\
\hline \multirow{13}{*}{$\begin{array}{l}\text { Ait } \\
\text { Mhamed }\end{array}$} & 7- 2014 & 1 & 6221 & 5 & 0,6 & I & $\mathrm{FH}$ & 423,3 \\
\hline & 7- 2014 & 2 & 14640 & 11 & 0,76 & I & FH & 500,5 \\
\hline & 7- 2014 & 3 & 15490 & 13 & 0,28 & I & FH & 428,6 \\
\hline & 7- 2014 & 4 & 6555 & 10 & 0,99 & I & $\mathrm{FH}$ & 392,6 \\
\hline & 7- 2014 & 5 & 11493 & 11 & 0,28 & I & FH & 413,1 \\
\hline & 7- 2014 & 6 & 6477 & 8 & 1,7 & I & FH & 582,2 \\
\hline & 7- 2014 & 7 & 11753 & 13 & 0,37 & I & $\mathrm{FH}$ & 326,5 \\
\hline & 7- 2014 & 8 & 6159 & 11 & 1,05 & I & FH & 436,5 \\
\hline & 7- 2014 & 9 & 12637 & 8 & 0,32 & I & FH & 508,7 \\
\hline & 7- 2014 & 10 & 23639 & 15 & 0,19 & II & FH & 512 \\
\hline & 7- 2014 & 11 & 45341 & 13 & 0,14 & II & FH & 411,6 \\
\hline & 7- 2014 & 12 & 21769 & 14 & 0,2 & II & FH & 515,8 \\
\hline & 7- 2014 & 13 & 14750 & 15 & 0,25 & $\mathrm{I}$ & $\mathrm{FH}$ & 376,9 \\
\hline \multirow[t]{5}{*}{ Ait Attab } & 7- 2014 & 14 & 50761 & 10 & 0,09 & II & FH & 394,8 \\
\hline & 7- 2014 & 15 & 7690 & 12 & 0,17 & I & $\mathrm{FH}$ & 426,6 \\
\hline & 7- 2014 & 16 & 7571 & 11 & 0,24 & $\mathrm{I}$ & FH & 401,4 \\
\hline & 7- 2014 & 17 & 8148 & 9 & 0,06 & I & FH & 541,8 \\
\hline & 7- 2014 & 18 & 37527 & 17 & 0,08 & II & FH & 315,5 \\
\hline \multirow{2}{*}{$\begin{array}{l}\text { Foum } \\
\text { Jemaa }\end{array}$} & 7- 2014 & 19 & 3133 & 8 & 0,42 & $\mathrm{I}$ & $\mathrm{FH}$ & 431,1 \\
\hline & 7- 2014 & 20 & 22653 & 9 & 0,02 & II & FH & 444,6 \\
\hline \multirow{7}{*}{$\begin{array}{l}\text { Azilal } \\
2014\end{array}$} & 7- 2014 & 21 & 18641 & 7 & 0,83 & $\mathrm{I}$ & $\mathrm{FH}$ & 375 \\
\hline & 7- 2014 & 22 & 25017 & 12 & 0,36 & II & $\mathrm{FH}$ & 547,5 \\
\hline & 7- 2014 & 23 & 10905 & 14 & 0,33 & $\mathrm{I}$ & FH & 510,2 \\
\hline & 7- 2014 & 24 & 8432 & 8 & 1,16 & $\mathrm{I}$ & $\mathrm{FH}$ & 602 \\
\hline & 7-2014 & 25 & 3206 & 11 & 0,78 & $\mathrm{I}$ & $\mathrm{FH}$ & 803 \\
\hline & 7- 2014 & 26 & 10089 & 13 & 0,42 & I & $\mathrm{FH}$ & 770,3 \\
\hline & 7- 2014 & 27 & 6196 & 8 & 0,88 & I & FH & 402,8 \\
\hline \multirow{14}{*}{$\begin{array}{l}\text { Azilal } \\
2015\end{array}$} & 7- 2015 & 28 & 50909 & 15 & 3,55 & II & Honeydew & 1165 \\
\hline & $7-2015$ & 29 & 98250 & 18 & 2,75 & II & Honeydew & 1063.5 \\
\hline & 7- 2015 & 30 & 203667 & 20 & 2,33 & III & Honeydew & 1247 \\
\hline & 7- 2015 & 31 & 1190667 & 14 & 3,48 & $\mathrm{~V}$ & Honeydew & 1148 \\
\hline & 7- 2015 & 32 & 28462 & 11 & 0,1 & II & Honeydew & 1431 \\
\hline & 7- 2015 & 33 & 94378 & 18 & 1,43 & II & Honeydew & 1017 \\
\hline & 7- 2015 & 34 & 85400 & 19 & 2,5 & II & Honeydew & 1055.5 \\
\hline & 7- 2015 & 35 & 65764 & 22 & 2,32 & II & Honeydew & 1130.5 \\
\hline & 7- 2015 & 36 & 92733 & 14 & 0,28 & II & FH & 720 \\
\hline & 7- 2015 & 37 & 25380 & 16 & 0,8 & II & FH & 636.5 \\
\hline & 7- 2015 & 38 & 15050 & 8 & 2,5 & I & Honeydew & 1362 \\
\hline & 7- 2015 & 39 & 37567 & 13 & 1,33 & II & Honeydew & 1365 \\
\hline & 7- 2015 & 40 & 194674 & 12 & 0,09 & III & FH & 381.7 \\
\hline & 7- 2015 & 41 & 404082 & 11 & 0,02 & III & Honeydew & 1456 \\
\hline Tanant & 7- 2015 & 42 & 78050 & 13 & 2,5 & II & Honeydew & 1099.5 \\
\hline
\end{tabular}



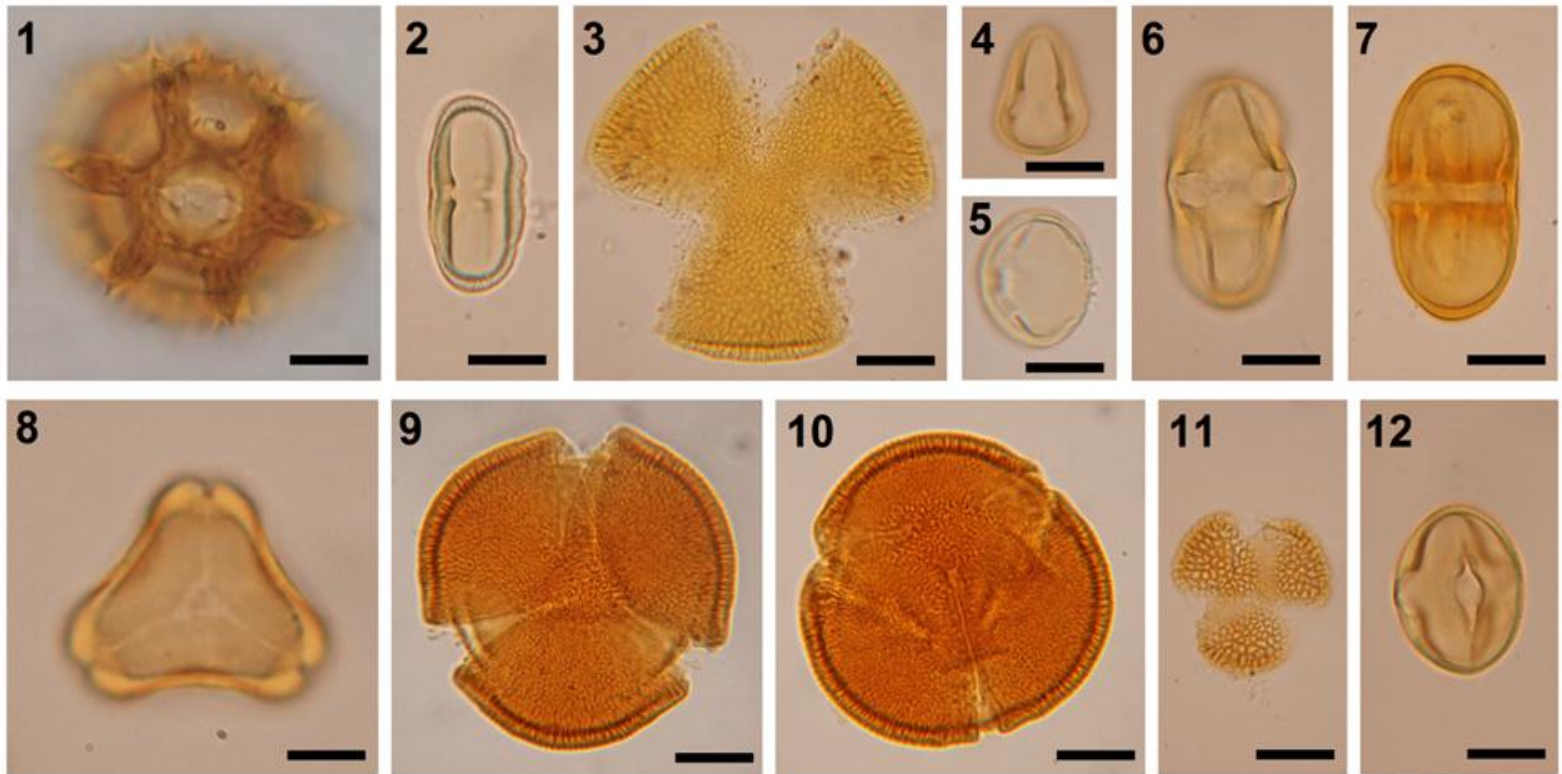

11
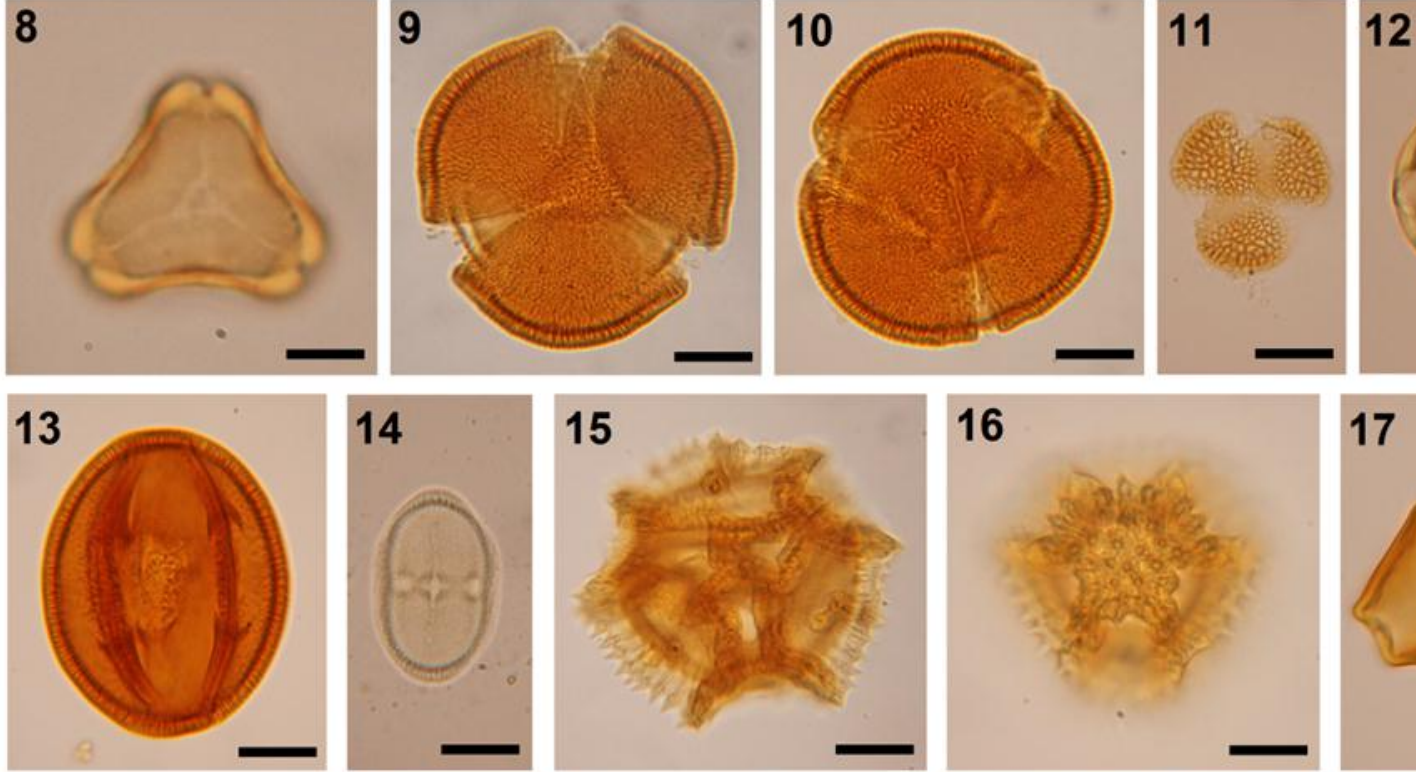

16
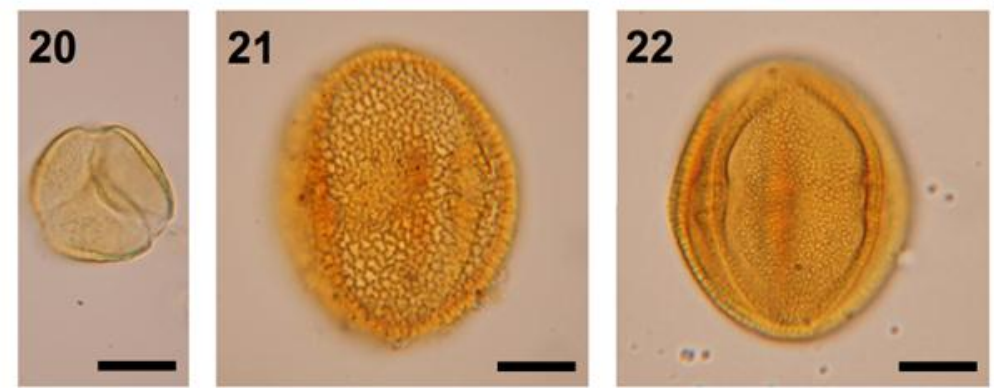

Fig. 2: Photon microscopy of the pollen morphology of the main nectariferous taxa (1 to 18) and low nectariferous (19 to 22); Scale bar $=10 \mu \mathrm{m}$.

1 : Cichorium Type ; 2 : Conium Type ; 3 : Convolvulus sp. ; 4 : Echinus sp. ; 5 : Reseda sp. ; 6 : Eryngium triquetrum ; 7 : Eryngium variifolium ; 8 : Eucalyptus sp. ; 9, 10 et $13:$ Euphorbia resinifera ; 11 : Hirschfeldia incana ; 12 : Lotus Type; 14 : Melilotus sp. ; 15: Scolymus hispanicus ; 16 : Taraxacum Type; 17 : Ziziphus lotus ; 18 : Trifolium Type; 19 : Papaver sp; 20 : Quercus ilex; 21 : Cistus laurifolius ; 22: Cistus villosus .

Pollen in equatorial view: $1,2,4-7,12-15,18,21-22$; Pollen in polar view : 3, 8-9, 11, 16-17; Pollen in slant view: 10, $19-20$. 
Table 2: Pollen spectrum of studied honeys (* nectariferous taxon)

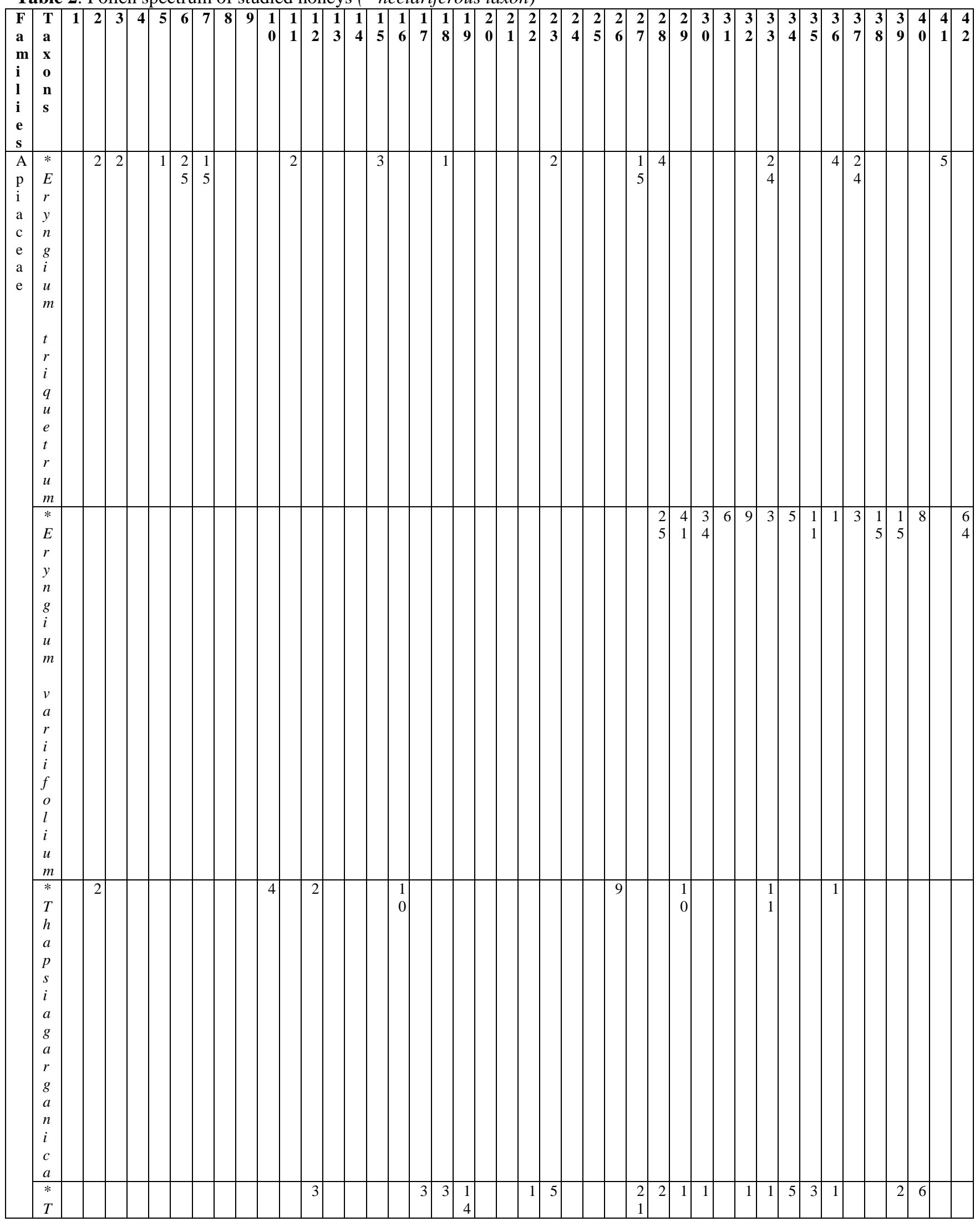




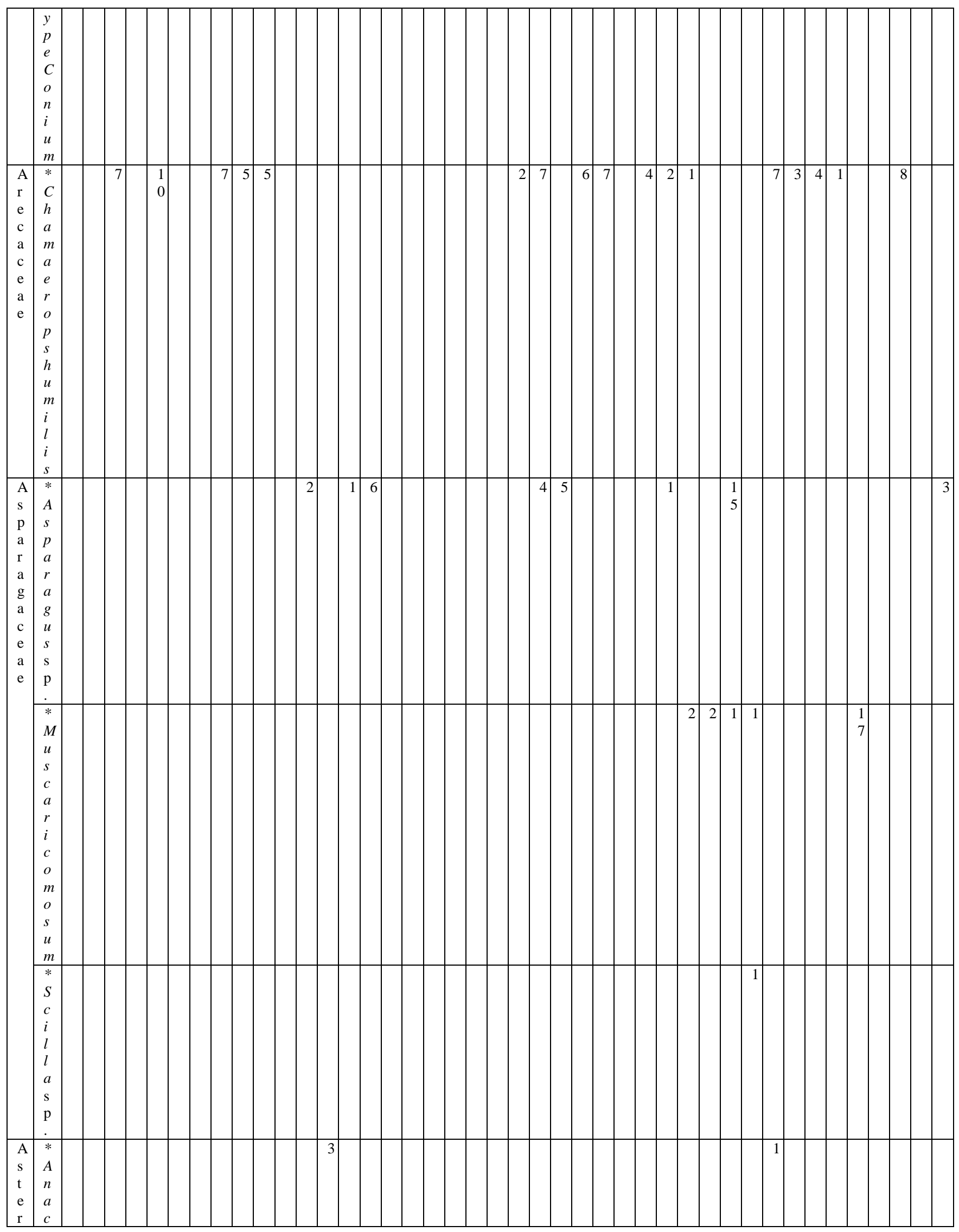




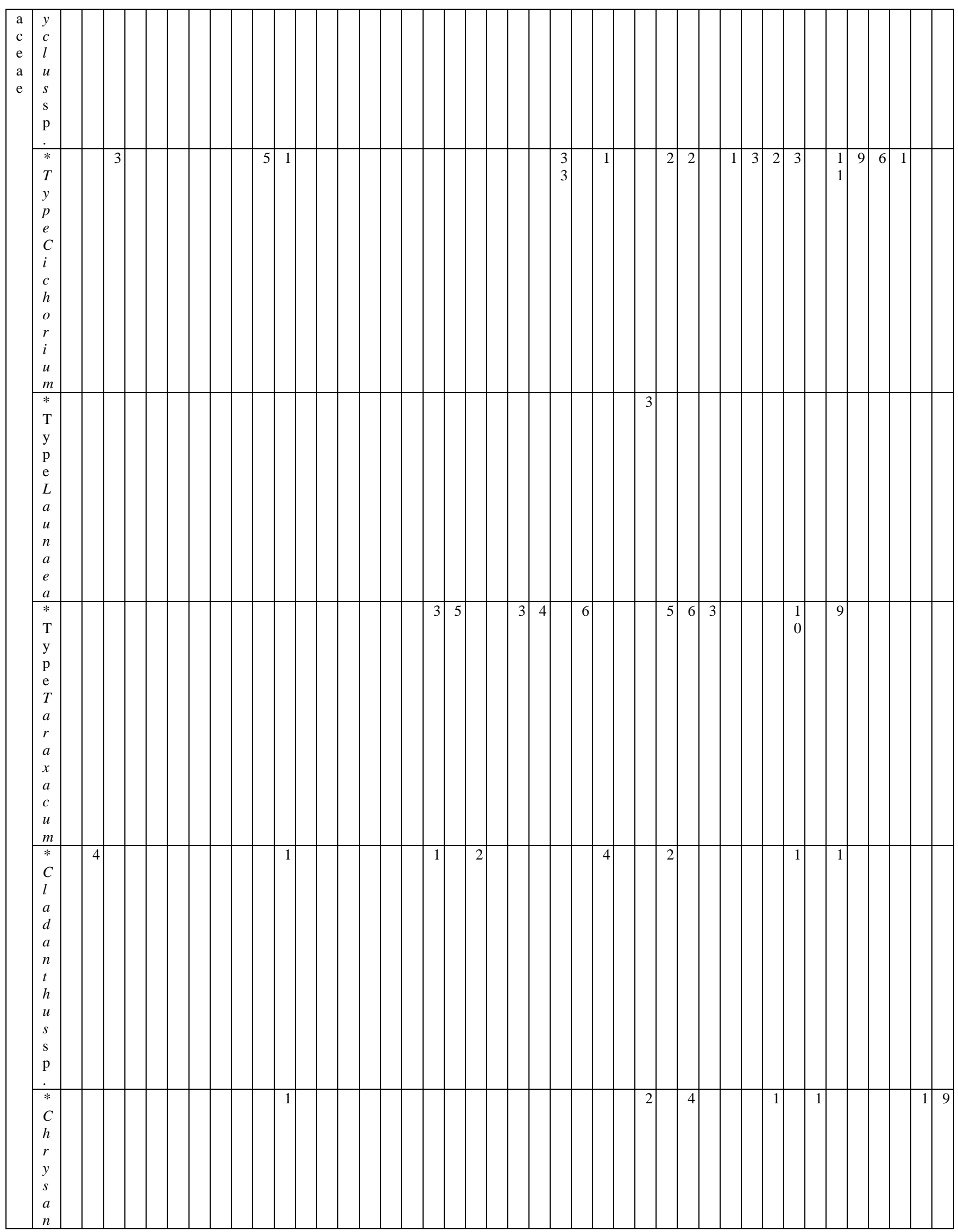




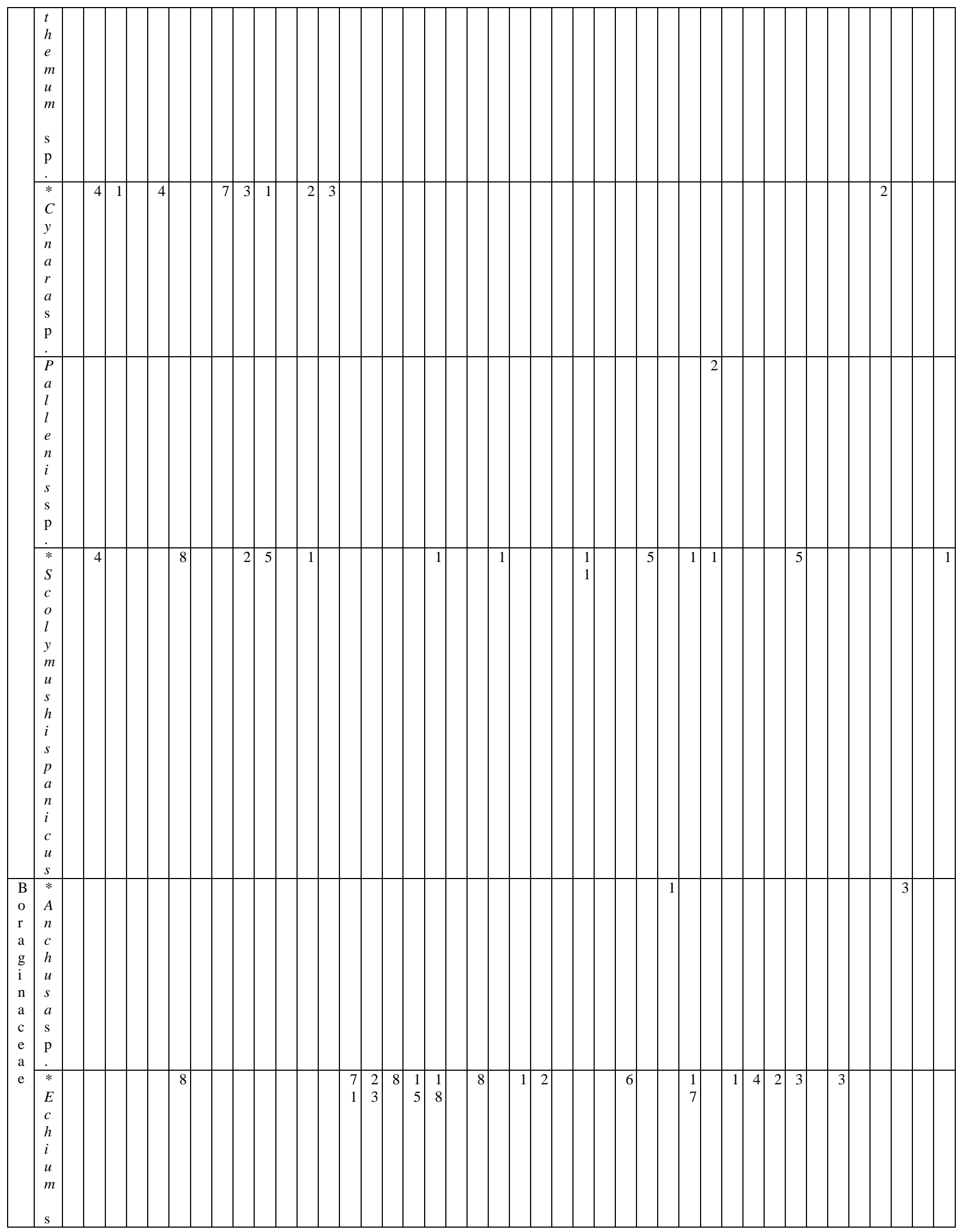




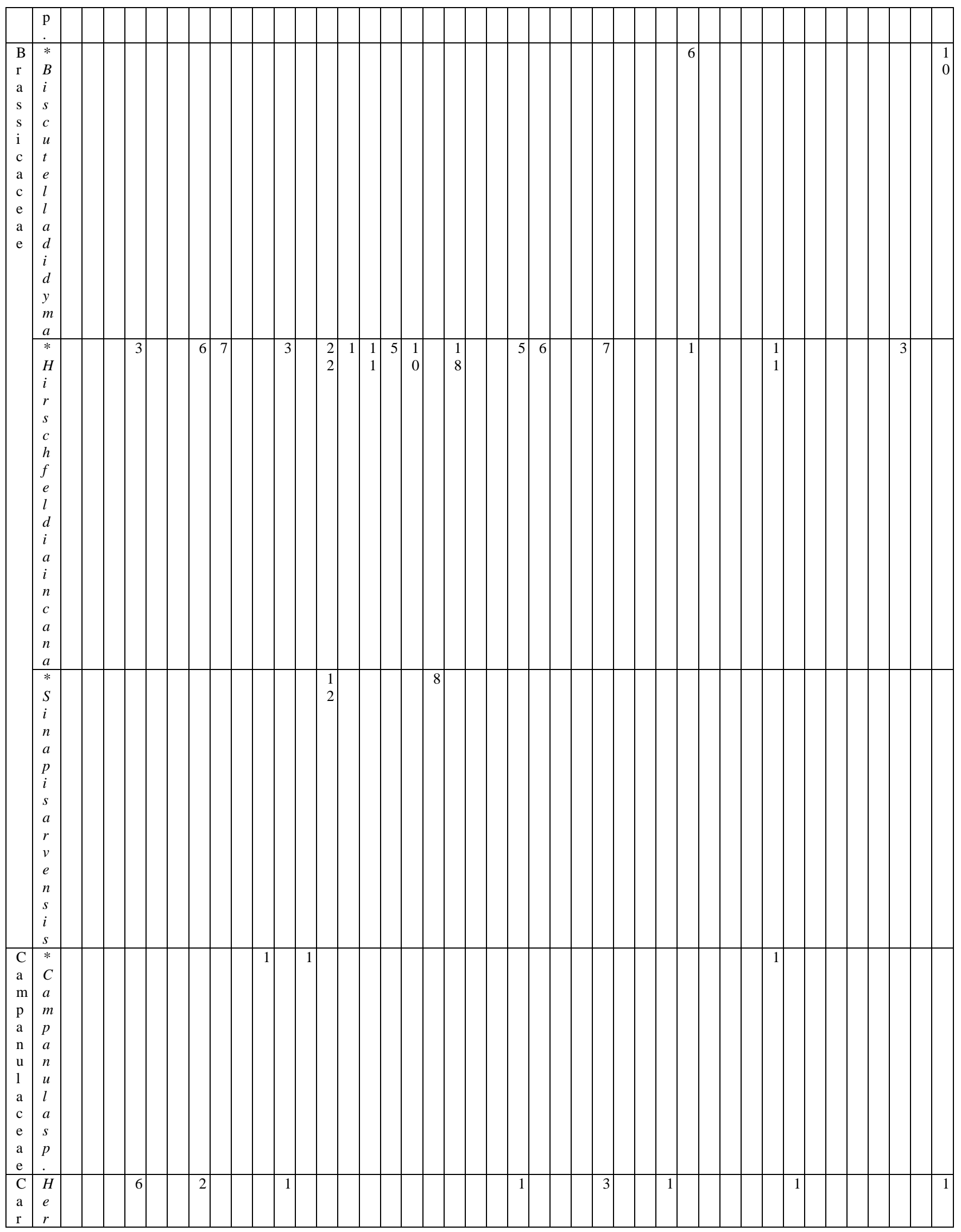




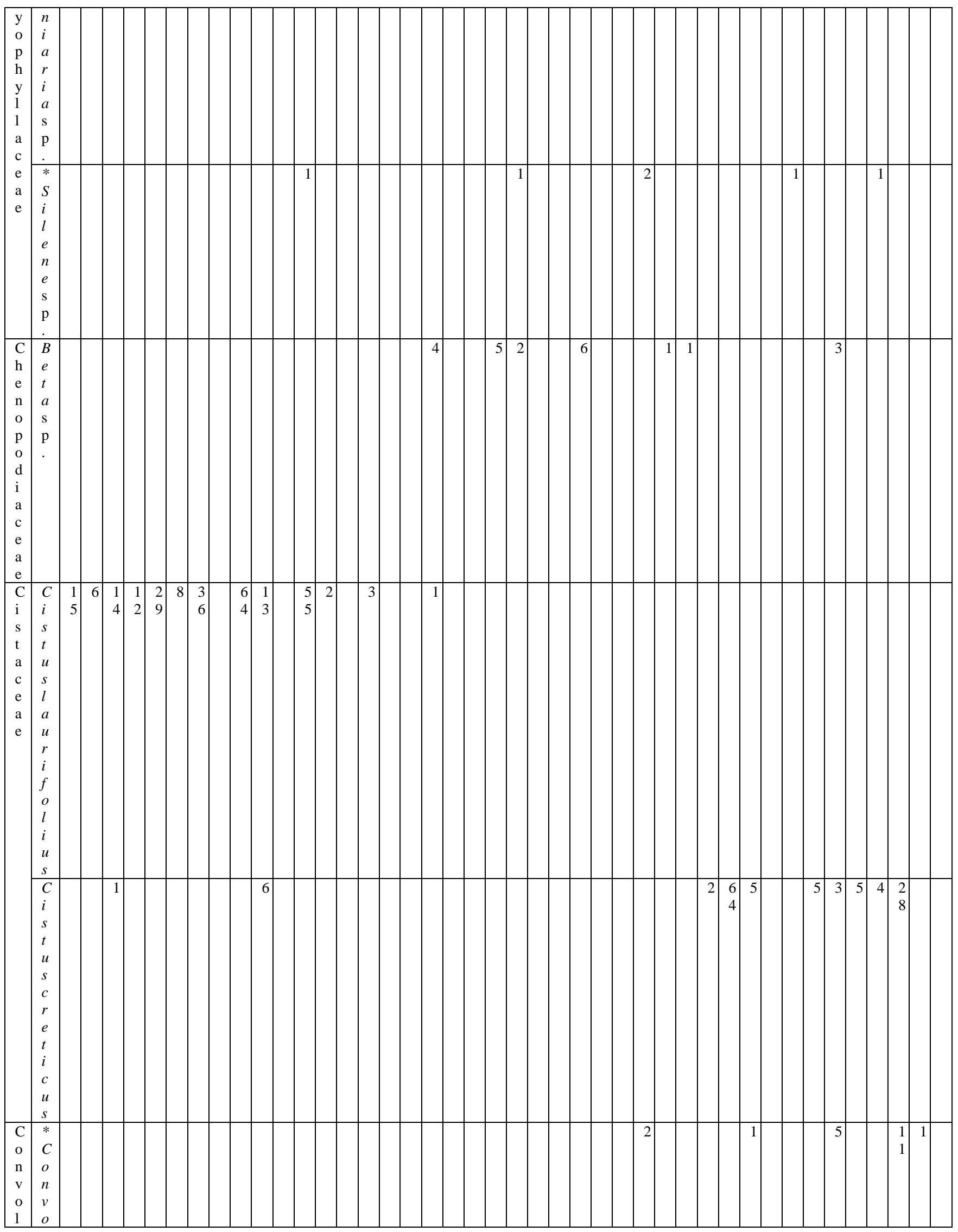




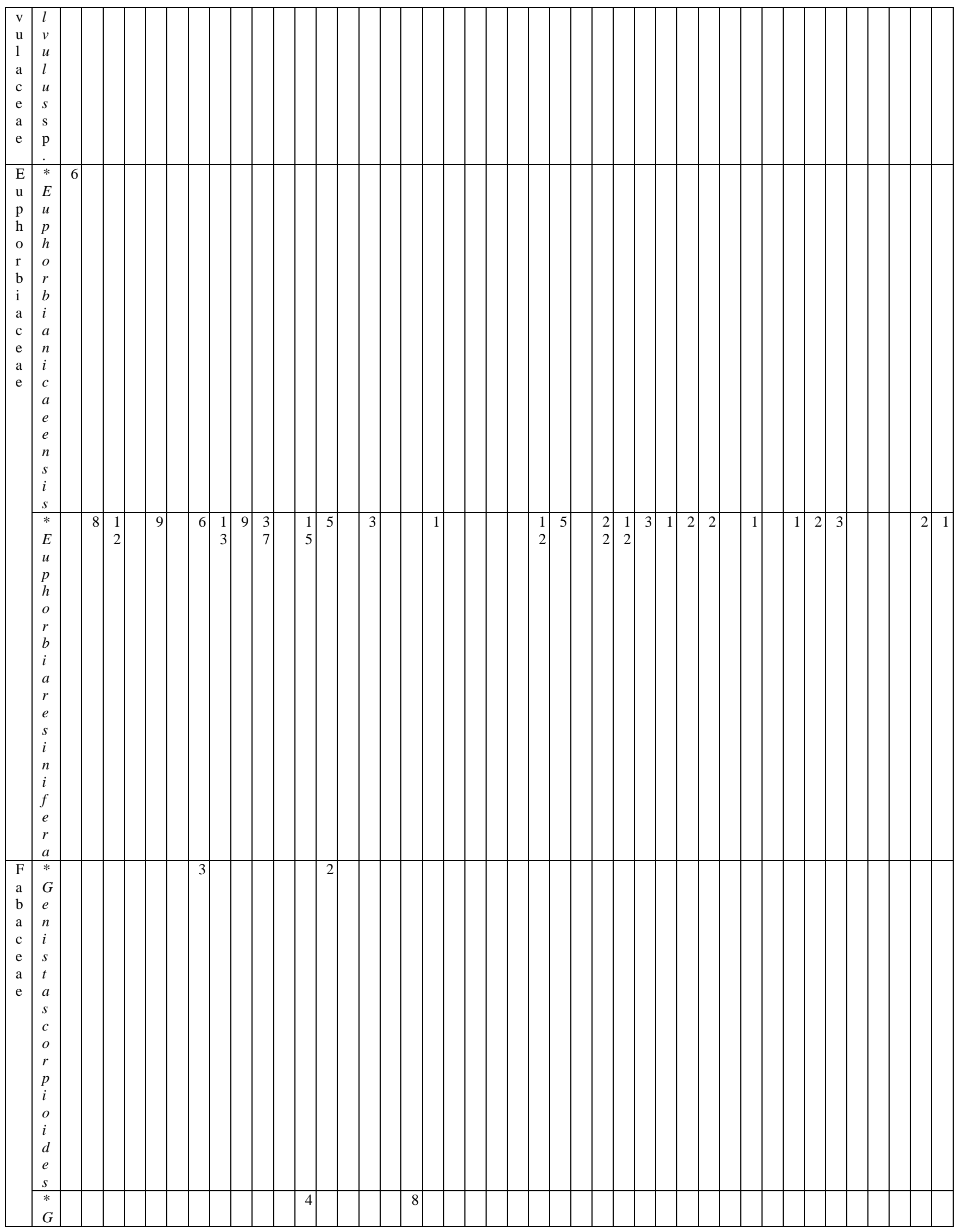




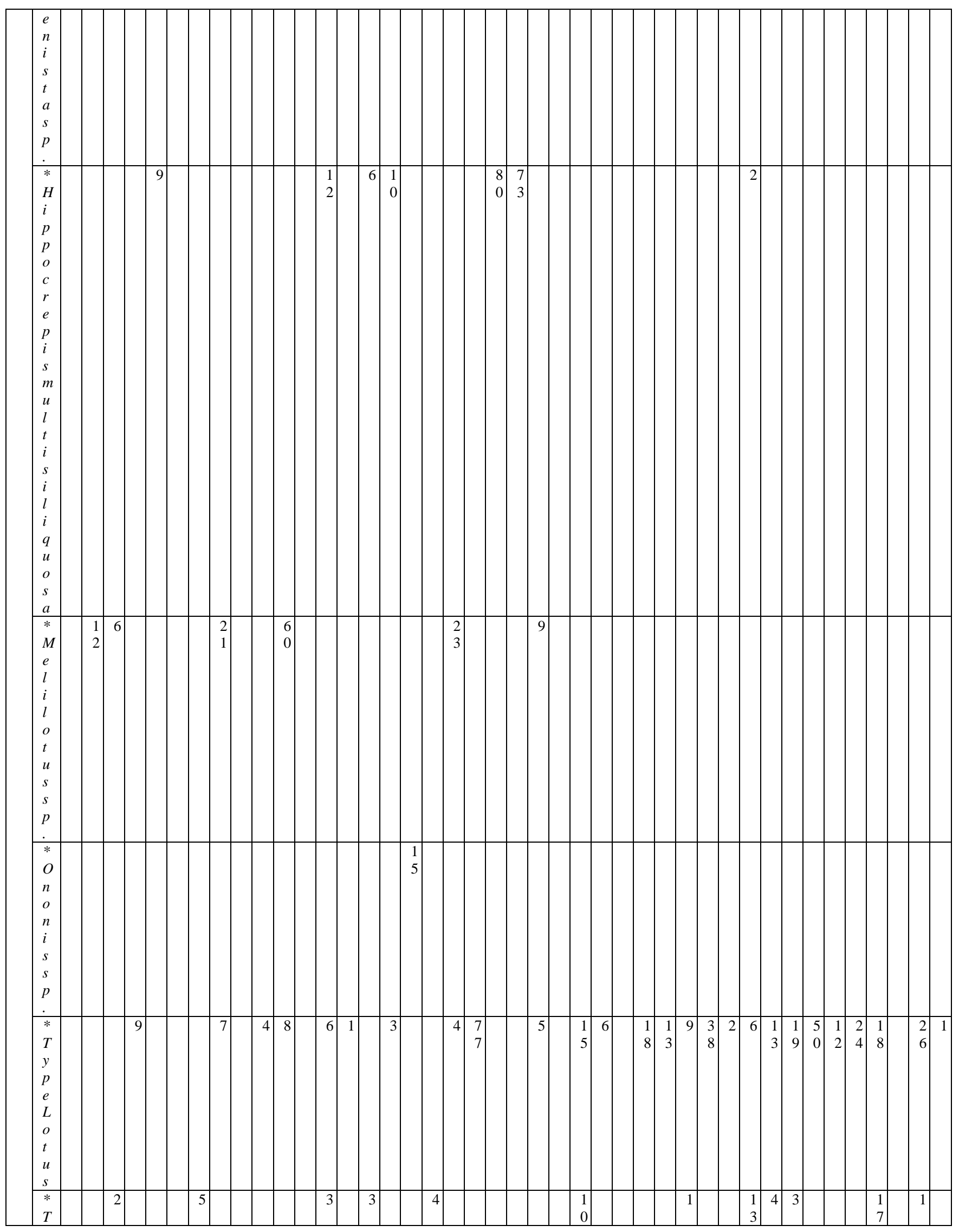




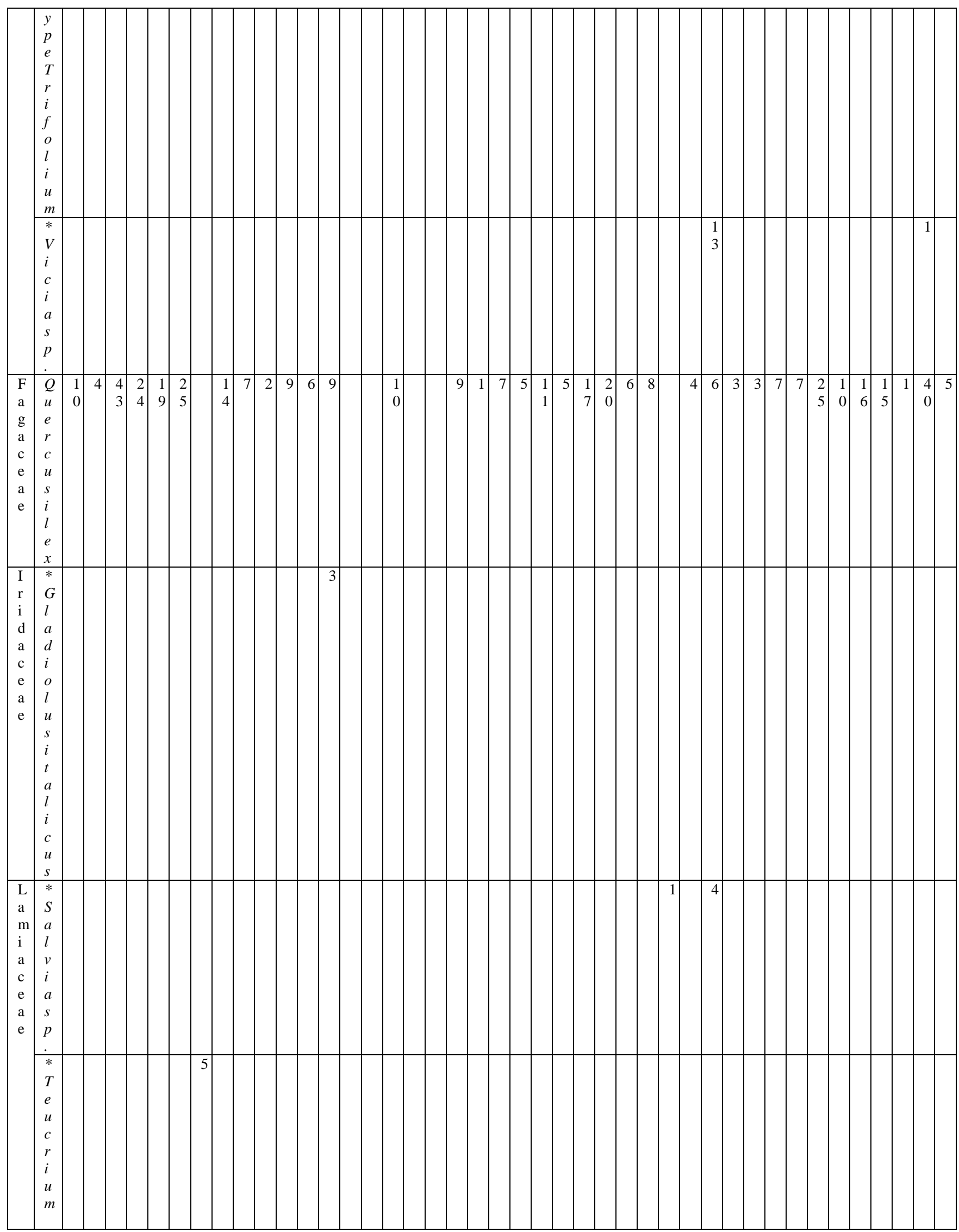




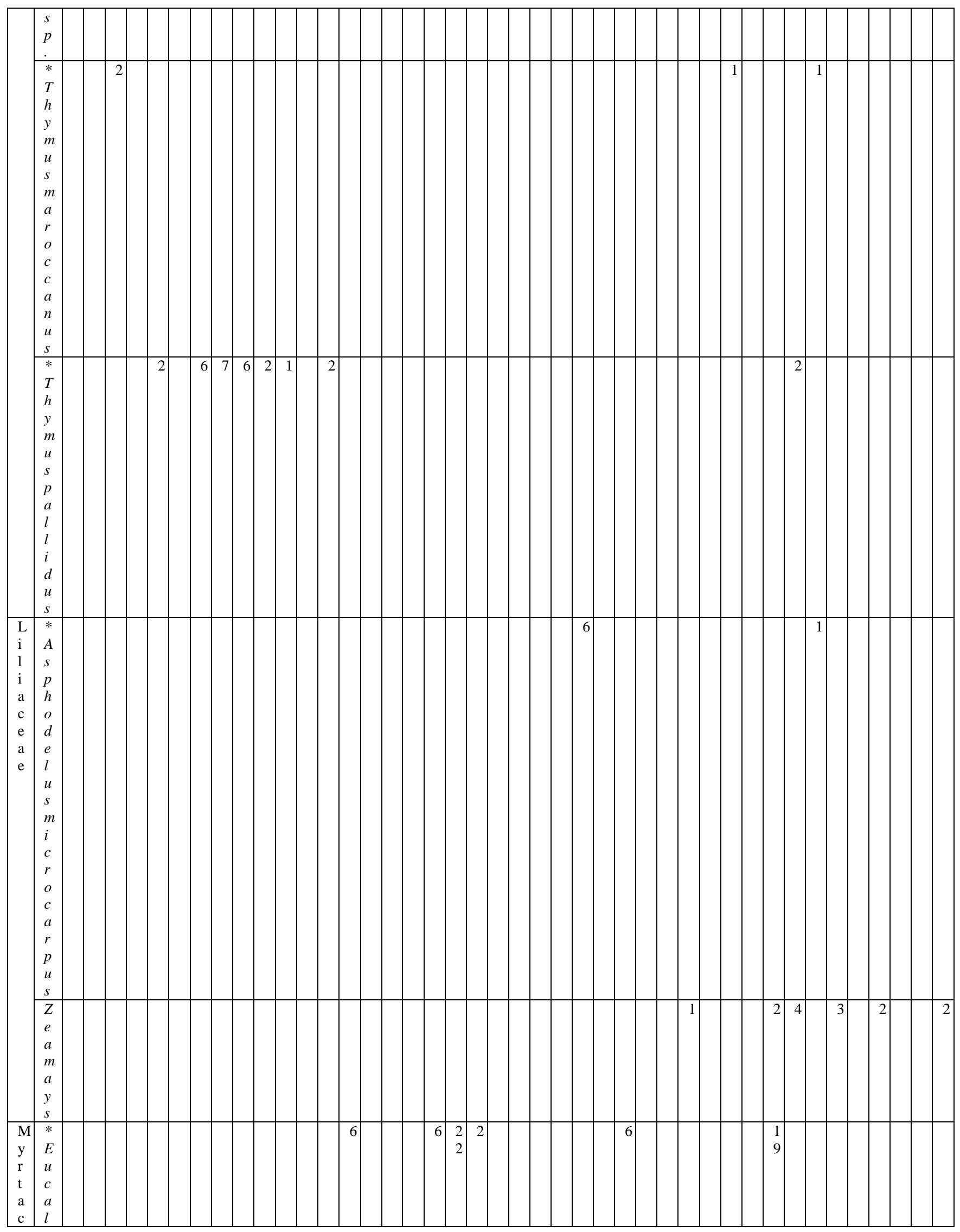




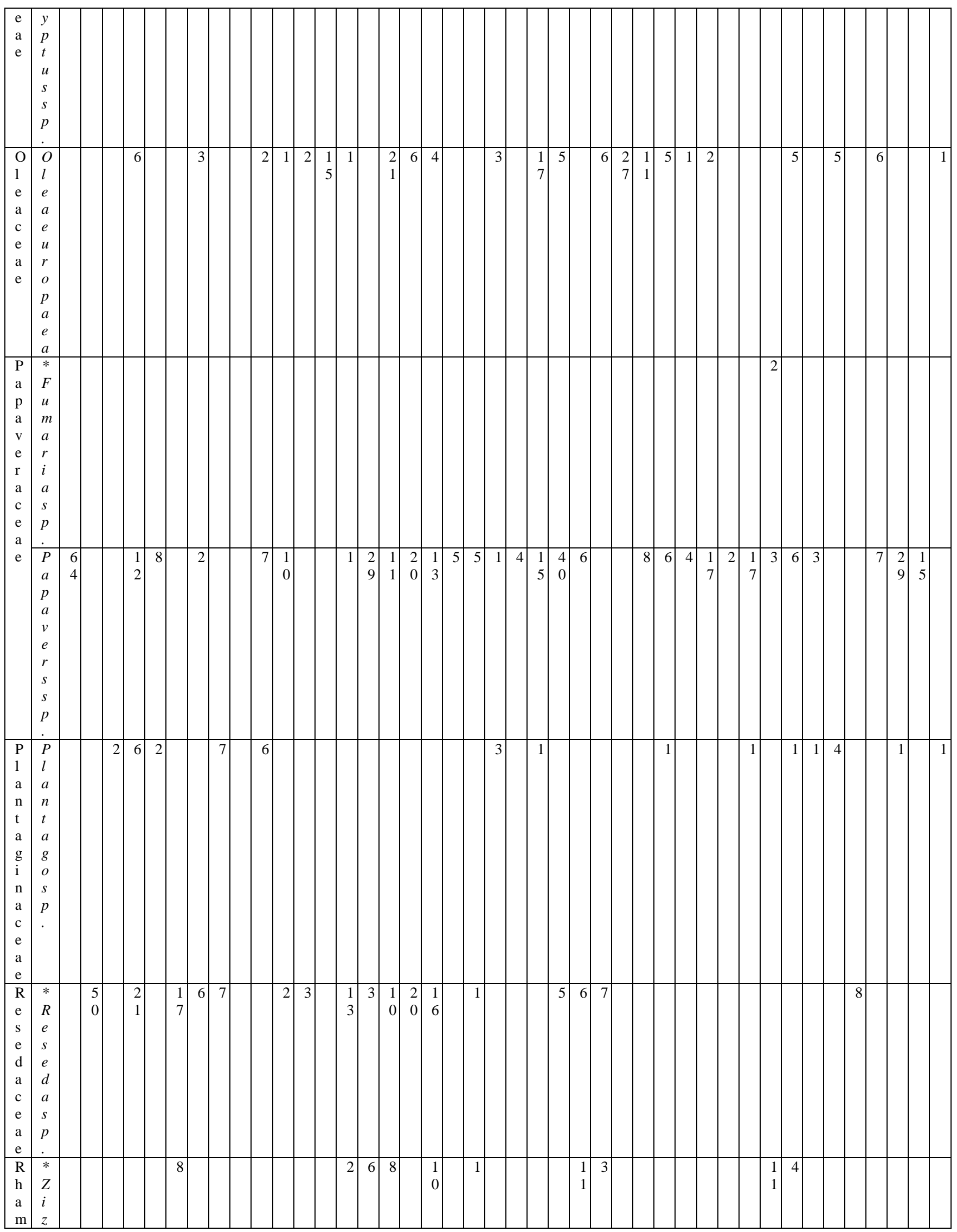




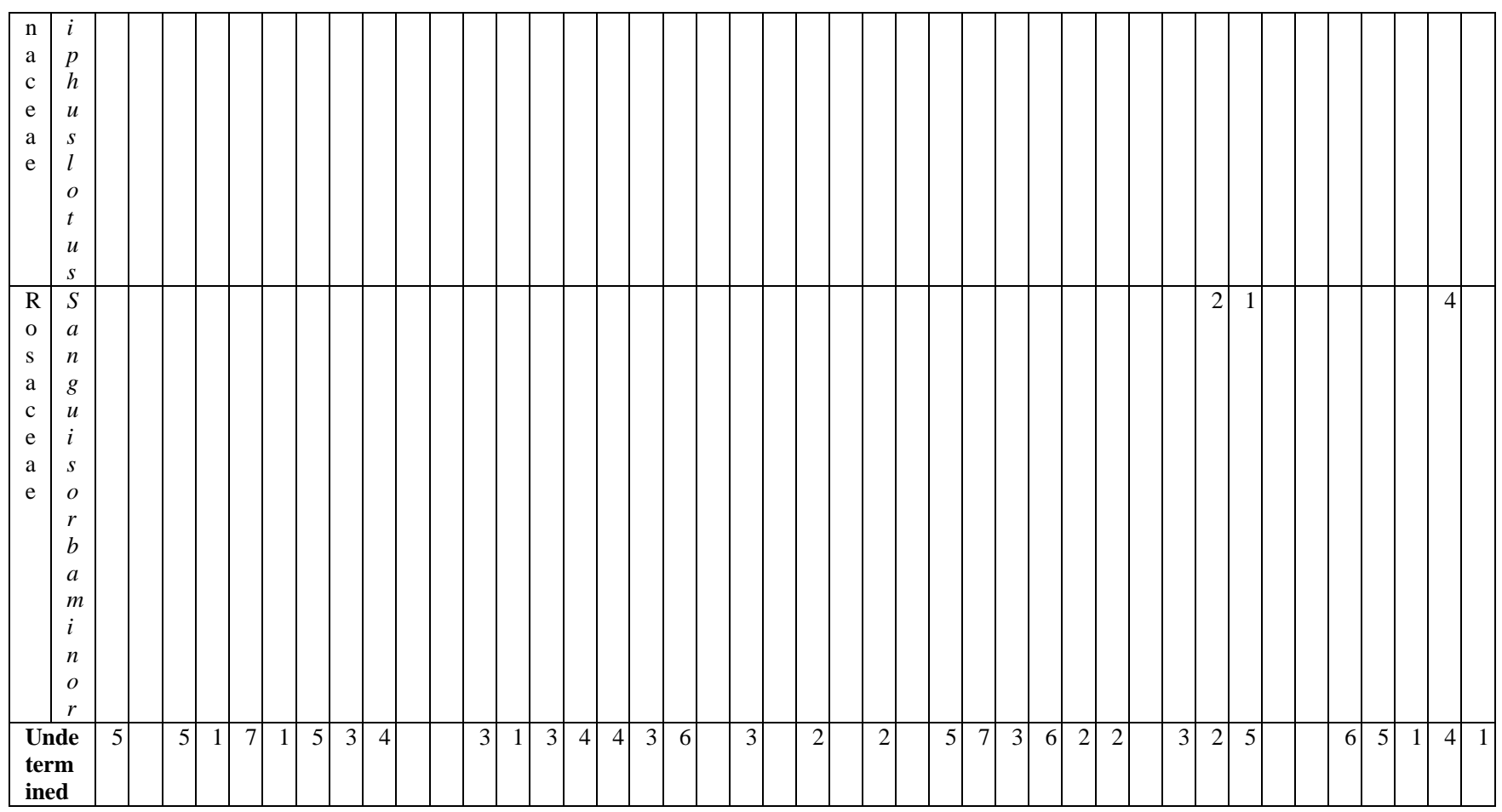




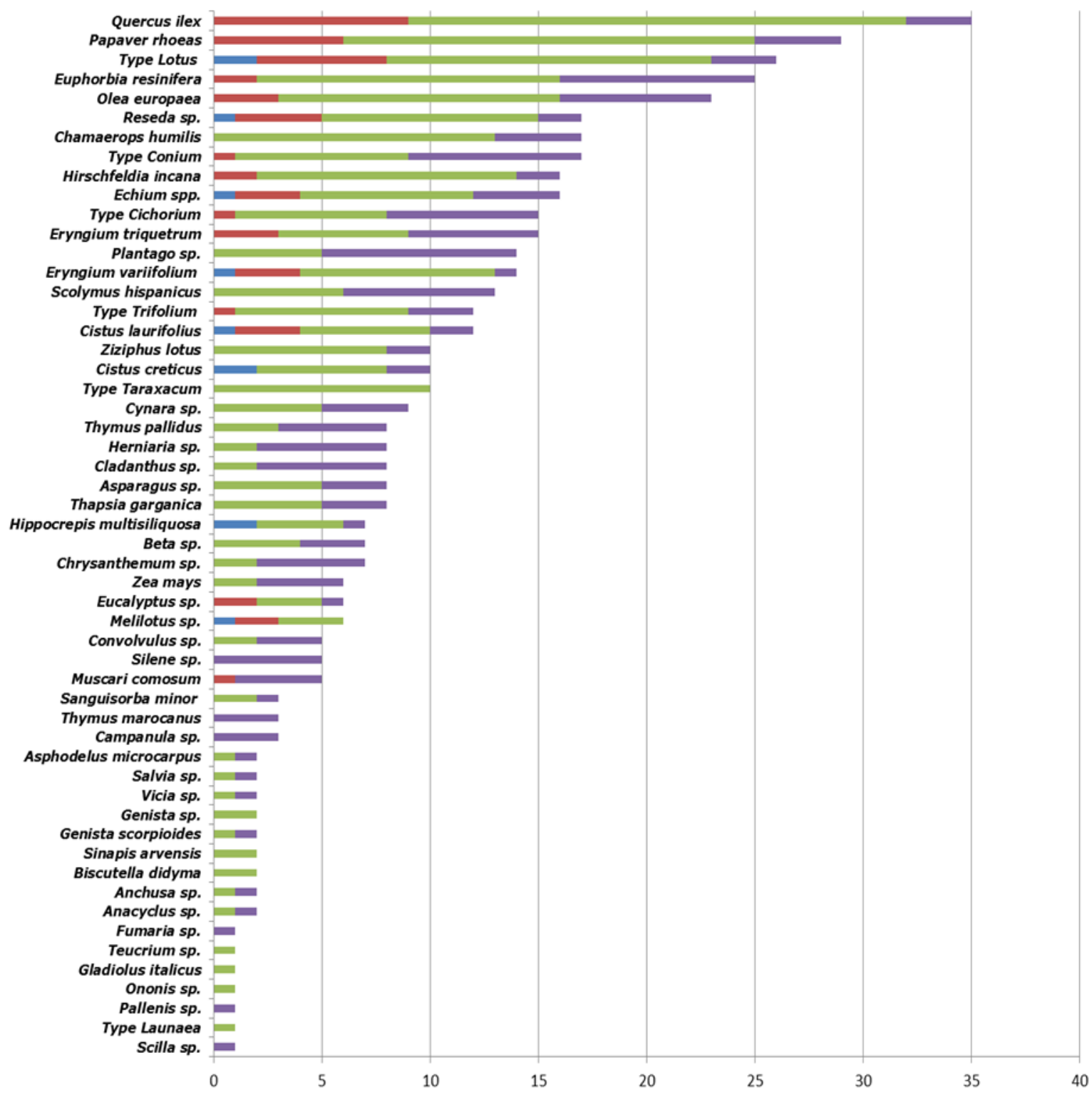

Fig. 3:-Number of pollen grains of the 55 taxa identified in the 42 honey samples represented in the four classes of pollen frequencies.

The best represented families are the Asteraceae (nine types), the Fabaceae (eight types), the Apiaceae and the Lamiaceae (four types), the Asparagaceae and the Brassicaceae (three types). The Boraginaceae, the Caryophyllaceae, the Cistaceae, the Euphorbiaceae and the Papaveraceae are represented by two types. A single pollen type represents each of the families of Arecaceae, Campanulaceae, Chenopodiaceae, Convolvulaceae, Fagaceae, Iridaceae, Liliaceae, Myrtaceae, Oleaceae, Plantaginaceae, Poaceae, Resedaceae, Rhamnaceae, and Rosaceae.

No pollen is present in all the studied honey. Although all these honeys were sampled in plant formations dominated by Euphorbia resinifera, only 25 samples contain pollen of this species, with a percentage ranging from less than 1 to $37 \%$. The most common pollens are those of Quercus ilex (36 samples), Papavers sp. (30 samples). Olea europaea is present in 23 samples, Chamaerops humilis in 17 and Echiumsp, Hirschfeldia incana and Reseda sp. in 16 samples (Fig.2). Table 2 summarizes the frequency of pollen in the samples studied as well as their class of abundance. 
For their botanical origin, and according to the electrical conductivity values (Table 1), all honeys harvested in 2014 are nectarous honey whereas in 2015, 12 are attributed to honeydew and 3 are from flowers.

Among the thirty flower honeys, seven are monofloral of E. resinifera (samples 2, 3, 5, 9, 10, 12, and 26) with a percentage of pollen grains from this species varying between $25 \%$ and $58 \%$ among pollen grains of nectariferous taxa. Euphorbia pollen is among the underrepresented group and a result of $25 \%$ of pollen presence is sufficient to qualify a honey as monofloral (Damblon, 1988; Terrab et al., 2014). These honeys have a low botanical content (five belong to Maurizio's class I (1979) and two to class II with an average of $=14027$ grains / 10g). Their honeydew index is very low (average $=0.362$ ), a characteristic value of monofloral honeys (Louveaux et al., 1970, 1978; Von Der Ohe, 2004). The remaining flower honeys are multifloral, and belong to classes I, II or III, with an average of 26953 grains / 10g and a low honeydew index (average $=0.508$ ).

Honeydew honeys have an electrical conductivity that varies between 1017 and $1456 \mu \mathrm{S} / \mathrm{cm}$, a honeydew index of less than 3 (average $=2.067$ ) for most samples and an average content of botanical elements with two samples belonging to class I, eight to class II, two to class III and one to class V (average $=196020$ ). The very large number of botanical elements of the last sample results from the fact that this honey was very adherent to the alveoli and we were forced to extract it by pressing (Table 1).

\section{Discussion:-}

The study was carried out during 2014 and 2015 characterized by a precocious flowering, a low yield of honey per hive (4 kg/hive for 2014 and $3 \mathrm{~kg} /$ hive for 2015) compared to a normal year $(11 \mathrm{~kg} / \mathrm{hive}$ on average) and a small contribution of Euphorbia resinifera to honey production. The melissopalynological characteristics of the studied samples did not reflect the dominance of E. resinifera, nor the sensory characteristics that allowed beekeepers to label honeys from the Azilal region as monofloral. Of the 42 samples analyzed, only seven (16.7\%) had characteristics of monofloral honey of Euphorbia resinifera, the others are either honeydew or multifloral.

\section{Early flowering of Euphorbia resinifera:}

The flowering period of E. resinifera is between June and July (Gattefossé and Vindt, 1954; Gómiz-García, 2001; Aafi et al., 2002). In recent years and according to beekeepers in the region, for a year with normal yield, flowering started from the second week of May. During the two years of study, the first flowers appeared in mid-April in the areas of Ait Attab, Foum Jemâa, and Tanant (840, 890, and 940 m of altitude respectively), late April-early May in Azilal $(1300 \mathrm{~m})$ and during the second week of May at Ait Mhamed $(2000 \mathrm{~m})$. These different findings reveal a stability of flowering for the mountainous area and a precocity more and more pronounced towards areas of low altitudes.

Early flowering has been reported by several authors in response to global warming (Defila and Clot, 2001 ; Menzel et al., 2005, 2006 ; Hovenden et al., 2008 ; Gallagher et al., 2009 ; Rumpff et al., 2010 ; Chmielewski et al. 2011; Anderson et al., 2012 ; Chambers et al., 2013 ; Rawal, 2014; Burghardt et al. 2016; Rather et al., 2018). Bakke (1936), had observed a comparable precocity to that of E. resinifera, at Euphorbia esulaL.1753, an invasive weed introduced in North America in the late 19th century. Under normal conditions, this species begins to flower in late May - early June (Hanson and Rudd, 1933; Bakke, 1936; Galitz and Davis, 1983; Hunt et al 2004; Gesch et al., 2007; John and Tilley, 2014). According to Bakke (1936), in 1934, the flowering of E. esula started in mid-May near Hawarden, Iowa. The author explains this anticipation of flowering by the softening of winter. It is the result of interannual variations of the spring climate for Foley et al., (2009). For Franks et al. (2007), summer drought is an early flowering factor.

\section{Evolution of pollen spectra and the contribution of E.resinifera to honey production:}

The presence of honeydew in all honeys results from the overlapping of the flowering period of Euphorbia resinifera with that of the green oak exudation (end of May to the beginning of June) whose honey is characterized by a honeydew index less than 3 (Sierra et al., 1987; Mateo and Bosch-Rei, 1998; Persano Oddo L. and Piro R. 2004; Atanassova et al., 2016; Jaafar et al., 2017; Terrab et al. 2019) and conifers (Juniperus oxycedrus, Juniperus phoenicea, and Tetraclinis articulata). 
Both years of study experienced modest rains ( $423 \mathrm{~mm}$ in 2014 and $274 \mathrm{~mm}$ in 2015), irregular in time and space and fluctuations of temperatures during the flowering period (Fig. 4). For 2014, the cumulative rainfall of the 4 months preceeding the flowering period (January-April) was $220 \mathrm{~mm}$ compared to $169 \mathrm{~mm}$ for 2015.
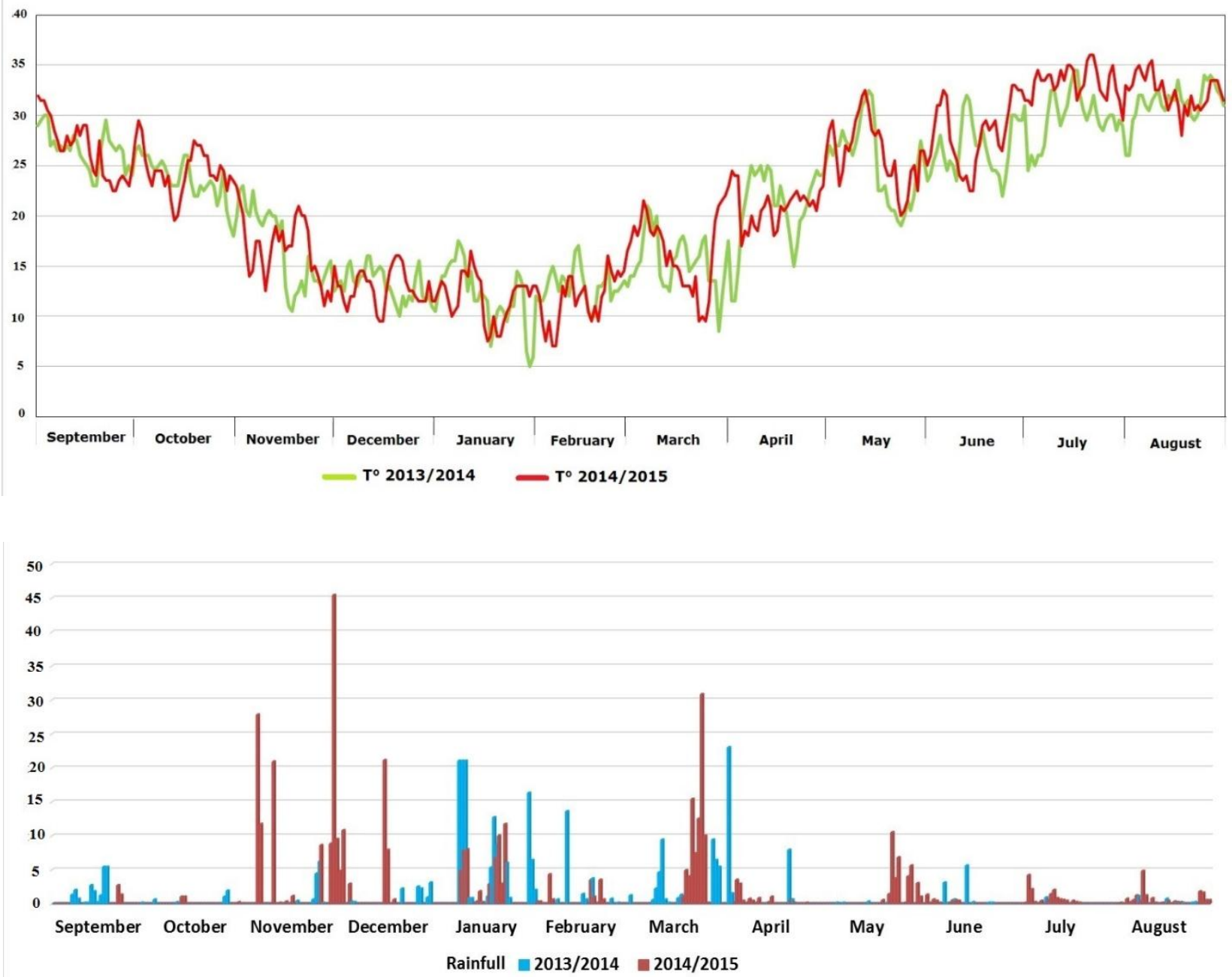

Fig 4:-Variation of temperature and rainfall in the Azilal region From September 2013 to August 2015. (meteomaroc)

Therefore, for 2014, the climatic conditions were relatively favorable (higher rainfall and cooler temperatures) for the production of nectar honeys (Table 1), although the yield remains modest. In the field, despite the "heat wave" that hit the region in mid-May (Fig3), E. resinifera in flowers dominated the nectarine flora in all areas studied until the end of June. The pollen spectra of the honeys sampled show an increase in the pollen percentages of the $E$. resinifera with altitude. In the highest areas, the percentages are more in line with the situation in the field (Table 2). Seven out of twenty honeys are monofloral (one in Azilal and six, higher, in Ait Mhamed). The honeys in the lower areas are multifloral and are low in pollen of the species (0 to $4.7 \%$ among nectarifers). In these areas, the species was less visited than other taxa.

Nectar is offered by plants as a reward to pollinators (Mačukanović-jocić and Djurdjević, 2005; Adgaba et al., 2017). Its production is controlled by environmental factors such as temperature, precipitation, atmospheric and soil moisture, solar radiation, atmospheric CO2 concentration, and altitude (Corbet 1978; Boose 1997; Lake and Hughes, 1999; Mačukanović-Jocić et al., 2008; Nedić et al., 2013). According to Petanidou and Smets (1996), Adgaba et al. (2012), Alqarni (2015) and Adgaba et al. (2017), there is a positive correlation between temperature rise and nectar production in species in semi-arid regions, up to a maximum, variable from one species to another, beyond which the secretion decreases and then ceases (Mačukanović-jocić and Djurdjević, 2005). Water stress also appears to limit 
nectar production (Carrión-Tacuriet al., 2012) and increase sugar concentration (Carroll et al., 2001). Domesticated bees prefer average sugar concentrations (Waller, 1972; Roubik and Buchmann, 1984) however low (Bolten and Feinsinger, 1978) or high concentrations of sugar (Adgaba et al., 2017) in nectariferous plants can limit melittophilia. For Mitchell and Waser (1992) and Mitchell (1993), there is a positive relationship between nectar production and frequency of pollinator visits.

In Morocco, over the past few decades, aridity has continuously transgressed from low to high altitudes and from south to north (Ait Brahim et al., 2016), in response to increasing temperatures and decreasing rainfall (Mokssit, 2012).

Thus, for areas of lower altitudes, more affected by temperature rise and drought, the early flowering of $E$. resinifera, negatively influenced its productivity of nectar, its attractiveness for honey bees, and thus its contribution to honey production. For the mountain areas (Azilal and Ait Mhamed), less affected by climatic variations, the stability of the flowering period of E. resinifera is responsible for a more attractive nectar productivity for bees and a sufficient contribution to producing monofloral honeys.

For 2015, there was no harvest for the sectors of Ait Attab and Foum Jemâa. In the Tanant area of comparable altitude but close to the l'Oued Lakhdar and Azilal, the composition of honeys was different compared to 2014. The samples are rich in honeydew. This is related to the evolution of climatic parameters and their impact on flora. As for 2014, the season started in good conditions. This allowed the hive to flourish and the bees to harvest the nectar. But the heat waves that occurred during the study period (Fig. 4), destroyed flowering and weakened the herd. The bees have consumed their stock. It was only after that they started storing honey again during the honeydew period (something that beekeepers found). Hence, the important part of honeydew in these samples and the low contribution of the nectariferous of which E. resinifera.

\section{Conclusions:-}

Honey is the product of a close collaboration between plants, which secrete the raw material (nectar and honeydew), and the bees that produce it. Studying it allows us to trace the evolution of honeybee-plant interaction under the control of natural and/or anthropogenic factors. Thus, using melissopalynology, this study has highlighted, for the first time, the relationship between the early flowering of Euphorbia resinifera, endemic species of Morocco, in response to global warming, on one hand, and its low nectar productivity, its attractiveness for bees and its contribution to honey making, on the other hand.

If the decline in honey yield from hives can be attributed to adverse weather conditions, affecting melliferous plants and bee colonies, several questions, about the relationship between early flowering and the contribution of Euphoribia resinifera in the elaboration of honey, need answers. We have already put forward various hypotheses such as the decrease in the quantity of nectar secreted by the species compared to other melliferous plants or the variation of its sugar concentration and / or the proportions of it. Studies are planned to unmask the origin of this low contribution to honey production, its impact on plant pollination and honey bees welfare, and the interaction between pollinators and entomophilous plants in general.

\section{References:-}

1. Aafi, A., Taleb, M. S., Fechtal M. (2002) : Espèces remarquables de la flore du Maroc. Centre National de la Recherche Forestière BP. 763 Agdal-Rabat Maroc, p. 52.

2. Aazza, S., Lyoussi, B., Antunes, D., Miguel M.G. (2014): Physicochemical characterization and antioxidant activity of 17 commercial Moroccan honeys. Int J Food Sci Nutr., 65: 449-457.

3. Adgaba, N., Al-Ghamdi, A., Tadesse, Y., Getachew, A., Awad, A. M., Ansari, M. J., Owayss, A. A., Mohammed, S. E. A., Alqarni, A. S. (2017): Nectar secretion dynamics and honey production potentials of some major honey plants in Saudi Arabia. Saudi J Biol Sci., 24: 180-191.

4. Adgaba, N., Awad, M.A., Al-Ghamdi, A.A., Alqarni, A.S., Radloff, S.E. (2012): Nectar of Ziziphus spinachristi (L.) Willd (Rhamnaceae): dynamics of secretion and potential for honey production. J. Apic. Sci., 56: 49-59.

5. Ait Brahim, Y., Bouchaou, L., Sifeddine, A., Khodri, M., Reichert, B., Cruz, F. W. (2016): Elucidating the climate and topographic controls on stable isotope composition of meteoric waters in Morocco, using stationbased and spatially-interpolated data. J. Hydrol., 543: 305-315. DOI: 10.1016/j.jhydrol.2016.10.001 
6. Alqarni, A.S. (2015): Honeybee foraging, nectar secretion, and honey potential of wild jujube trees, Ziziphus nummularia. Neotrop. Entomol., 44: 232-241.

7. Anderson, J.T., Inouye, D., Mckinney, A., Colautti, R., Mitchell-Olds, T. (2012): Phenotypic plasticity and adaptive evolution contribute to advancing flowering phenology in response to climate change. Proc. R. Soc. B., 279: 3843-3852.

8. Anonymous (2012) : Arrêté du ministre de l'agriculture et de la pêche maritime $\mathrm{N}^{\circ} 1721-12$ Reconnaissance de l'IGP « Miel d'Euphorbe Tadla-Azilal » et homologation du cahier des charges y afférent : Bulletin officiel $n^{\circ}$ 6074, p. 2524-2525.

9. Anonymous (2014) : Royaume du Maroc: Cinquième rapport national sur la mise en œuvre de la convention sur la diversité biologique, Rabat, p. 135.

10. Atanassova, J., Lazarova, M., Yurukova, L. (2016): Significant parameters of Bulgarian honeydew honey. J. Cent. Eur. Agric., 17: 640-651.

11. Bakke, A. L. (1936): Leafy spurge, Euphorbia esula L. Iowa Agric. Exp. Stn. Res. Bull., 198: 209-245.

12. Benabid A. (2000) : Flore et écosystème du Maroc : évaluation et préservation de la biodiversité. In : Ibis Press, Paris, p. 80.

13. Bettar, I., Gonzalez-Miret, M.L., Hernanz, D., Marconi, A., Heredia F.J., Terrab A. (2015): Characterisation of Moroccan Spurge (Euphorbia) honeys by their physicochemical characteristics, mineral contents and color. Arab J Chem., doi:10.1016/j.arabjc.2015.01.003.

14. Bogdanov, S., Lüllmann, C., Martin, P., von der Ohe, W. , Russmann, H., Vorwohl, G., Persano Oddo, L., Sabatini, A. G., Marcazzan, G. L., Piro, R., Flamini, C., Morlot, M., Lheretier, J., Borneck, R., Marioleas, P., Tsigouri, A., Kerkvliet, J., Ortiz, A., Ivanov, T., D'Arcy, B., Mossel, B., Vit, P. (1999): Honey quality, methods of analysis and international regulatory standards: review of the work of the International Honey Commission. Mitt. Lebensm. Hyg., 90: 108-125.

15. Bogdanov, S., Ruoff, K., Persano Oddo, L. (2004): Physico-chemical methods for the characterisation of unifloral honeys: a review. Apidologie., 35: 4-17.

16. Bolten, A. B., Feinsinger P. (1978): Why do hummingbird flowers secrete dilute nectar?. Biotropica., 10: 307309.

17. Boose D.L. (1997): Sources of variation in floral nectar production rate in Epilobium canum (Onagraceae): Implications for natural selection. Oecologia., 110: 493-500.

18. Bouhlali, E.D.T., Bammou, M., Sellam, K., Ramchoun, M., Benlyas, M., Alem, C., Filali-Zegzouti, Y. (2016): Evaluation of antioxidants, antibacterial and antifungal activities of eleven monofloral honey samples collected from Morocco. J. Chem. Pharm. Res., 8: 299-306.

19. Burghardt, L.T., Runcie, D.E., Wilczek, A.M., Cooper, M.D., Roe, J.L., Welch, S.M., Schmitt, J. (2016): Fluctuating, warm temperatures decrease the effect of a key floral repressor on flowering time in Arabidopsis thaliana. New Phytol., 210: 564-576. http://dx.doi.org/10.1111/nph.13799.

20. Carrión-Tacuri, J., Berjano, R., Guerrero, G., Figueroa, M.E., Tye, A., Castillo, J.M. (2012): Nectar production by invasive Lantana camara and endemic L. peduncularis in the Galápagos Islands. Pacific Science., 66: 435445.

21. Carroll A.B., Pallardy S.G., Galen C. (2001): Drought stress, plant water status, and floral trait expression in fireweed, Epilobium angustifolium (Onagraceae). Am. J. Bot., 88: 438-446.

22. Chakir, A., Romane, A., Marcazzan, G. L., Ferrazzi, P. (2016): Physicochemical properties of some honeys produced from different plants in Morocco. Arab. J. Chem., 9: 946-954.

23. Chambers, L.E., Altwegg, R. , Barbraud, C. , Barnard, P., Beaumont, L.J., Crawford, R. J. M. , Durant, J. M. , Hughes, L., Keatley, M. R., Low, M. , Morellato, P. C., Poloczanska, E. S., Ruoppolo, V., Vanstreels, R. E. T. , Woehler, E. J., Wolfaardt, A. C. (2013): Phenological Changes in the Southern Hemisphere. PLoS ONE., 8: e75514. doi:10.1371/journal.pone.0075514

24. Chmielewski, F-M., Blümel, K., Hennige, Y., Blanke, M., Weber, R.W.S., Zoth M. (2011): Phenological models for the beginning of apple blossom in Germany. Meteorol. Z., 20: 487-496

25. Corbet, S. (1978): Bee visits and the nectar of Echium vulgare L. and Sinapis alba L. Ecol. Entomol., 3: 25-37.

26. Crousilles, A. (2014) : Usages, propriétés antibactériennes et physicochimie de miels marocains. Diplôme d'État de Docteur en Pharmacie, Université de Montpellier I, Montpellier.

27. Damblon F. (1988) : Caractérisation botanique, écologique et géographique des miels du Maroc. Travaux de la Section Scientifique et Technique, Institut Français de Pondichery., 25 : 309-329.

28. Defila, C. and Clot B. (2001): Phytophenological trends in Switzerland. Int J Biometeorol., 45: 203-207 
29. Fennane, M., Ibn Tattou, M., Ouyahya, A., Mathez, J., El Oulaidi, J. (2007): Flore pratique du Maroc. Manuel de détermination des plantes vasculaires, volume 2. Travaux de l'Institut Scientifique, Sér. Botanique, Rabat. p. 126.

30. Foley, M.E., Anderson, J.V., Horvath. D.P. (2009): The effects of temperature, photoperiod, and vernalization on regrowth and flowering competence in Euphorbia esula (Euphorbiaceae) crown buds. Botany., 87: 986-992.

31. Franks, S. J.; Sim, S.; Weis, A.E. (2007): Rapid evolution of flowering time by an annual plant in response to a climate fluctuation. Proc. Natl. Acad. Sci. U. S. A, 104: 1278-1284

32. Galitz, D.S., Davis, D. G. (1983): Leafy Spurge Physiology and Anatomy. N. Dak. Farm Res., $20: 20-26$.

33. Gallagher, R. V., Hughes, L., Leishman, M. R. (2009): Phenological trends among Australian alpine species: using herbarium records to identify climate-change indicators. Aust. J. Bot., 57: 1-9, https://doi.org/10.1071/BT08051

34. Gattefosse, J. and Vindt, J. (1954): Les Euphorbes cactiformes du Maroc. Cactus., 41 : 65-72.

35. Gesch, R. W., Palmquist, D., Anderson, J. V. (2007): Seasonal Photosynthesis and Partitioning of Nonstructural Carbohydrates in Leafy Spurge (Euphorbia esula). Weed Sci., 55: 346-351

36. Gómiz-García, F. (2001): Flora selecta marroquí. Francisco Javier Navarro Díez: Amábar, SL., Burgos, p. 140.

37. Hanson, H.C. and Rudd, V.E. (1933): Leafy spurge life history and habits. North Dakota Agric. ColI. Agric. Exp. Stn. Bull., 226: 1-24.

38. Hovenden, M. J., Wills, K. E., Schoor, J. K. V., Williams, A. L., and Newton, P. C. D. (2008): Flowering phenology in a species-rich temperate grassland is sensitive to warming but not elevated CO2. New Phytolo., 178: 815-822. doi: 10.1111/j.1469-8137.2008.02419.x

39. Hunt, E. R., Mcmurtrey, JR., J. E., Williams, A. E. P., Corp, L. A. (2004): Spectral characteristics of leafy spurge (Euphorbia esula) leaves and flower bracts. Weed Sci., 52: 492-497.

40. Jaafar, K., Haidar, J., Kuraydiyyah, S., Ghaddar, T., Knio, K., Ismail B., Toufeili I. (2017): Physicochemical, melissopalynological and antioxidant properties of artisanal honeys from Lebanon. J. Food Sci. Technol., 54: 2296-2305.

41. Lake, J. C. and Hughes, L. (1999): Nectar Production and Floral Characteristics of Tropaeolum majus L. Grown in Ambient and Elevated Carbon Dioxide. Ann Bot., 84: 535-541.

42. Louveaux, J., Maurizio, A., Vorwohl, G. (1970) : Commission Internationale De Botanique Apicole De L’U.I.S.B.: Les méthodes de la mélissopalynologie. Apidologie., 1: 211-227.

43. Louveaux, J., Maurizio, A., Vorwohl, G. (1978): Methods of Melissopalynology, Bee World., 59: $139-157$.

44. Mačukanović-jocić, M. and Djurdjević, L. (2005): Influence of microclimatic conditions on nectar exudation in Glechoma hirsuta W. K. Arch. Biol. Sci., 57: 119-126.

45. Mačukanović-Jocić, M., Dajić Stevanović, Z., Jarić, S., Đurđević L. (2008): Nectar secretion in basil (Ocimum basilicum L.) grown in different soil conditions. J. Apic. Res., 47: 89-90. DOI: 10.1080/00218839.2008.11101431

46. Mateo, R. and Bosch-Reig, F. (1998): Classification of Spanish Unifloral Honeys by Discriminant Analysis of Electrical Conductivity, Color, Water Content, Sugars, and pH. J. Agric. Food Chem., 46: 393-400.

47. Maurizio, A. (1979): Microscopy of honey. In: Honey. A comprehensive survey, Crane (ed). Heinemann: London, pp. $240-257$.

48. Menzel, A., Estrella, N., Testka A. (2005): Temperature response rates from long-term phenological records. Clim. Res., 30: 21-28.

49. Menzel, A., Sparks, T.H., Estrella, N., Koch, E., Aasa, A., Ahas, R., Alm-Kubler, K., Bissolli, P. , Braslavska, O., Briede A. et al. (2006): European phenological response to climate change matches the warming pattern. Glob Chang Biol., 12: 1969-1976.

50. Mitchell, R.J. (1993): Adaptive significance of Ipomopsis aggregata nectar production: observation and experiment in the field. Evolution., 47: 25-35.

51. Mitchell, R.J. and Waser, N. M. (1992): Adaptive significance of Ipomopsis aggregata nectar production: Pollination success of single flowers. Ecology., 73: 633-638.

52. Mokssit, A. (2012) : L'état du changement climatique et ses impacts au Maroc : Le point sur le changement climatique au Maroc. In : Environnement et Changement Climatique au Maroc. Diagnostic et Perspectives (ed). Zeino-Mahmalat E., Bennis A., Eds., Konrad-Adenauer-Stiftung E. V., Rabat, Maroc., p. 35-39.

53. Moore, P. D., Collinson, M., Webb, J. A. (1991): Pollen Analysis. Blackwell scientific publications. 2ed (ed). Blackwell Scientific Publications: Oxford, p. 216.

54. Moujanni, A., Terrab, A., Eddoha, R., Nasser, B., Benbachir, M., Chaouqy, N. E. , Bouzid, T. , Essamadi, A. K. (2017): Microbiological quality of Moroccan labeled Euphorbia resinifera honey. J. microbiol. biotechnol. food sci., 6: 1188-1194. 
55. Naman, M., Faid, M., El Adlouni, C. (2005): Microbiological and physico-chemical properties of Moroccan honey. Int J Agric Biol., 7: 773-776.

56. Nedić, N., Mačukanović-Jocić, M., Rančić, D., Rrøslett, B., Šoštarći, I., Stevanović, Z.D., Mladenović, M. (2013): Melliferous potential of Brassica napus L. subsp napus (Cruciferae). Arth.-Plant Int., 7: 323-333. DOI: 10.1007/s11829-013-9247-2

57. Ohe, W. Von Der, Persano Oddo, L., Piana, M.L., Morlot, M., Martin, P. (2004): Harmonized methods of melissopalynology. Apidologie., 35: 18-25.

58. Persano Oddo, L. and Piro R. (2004): Main European unifloral honeys: descriptive sheets, Apidologie., 35: 3881.

59. Petanidou, T., Smets E. (1996): Does temperature stress induce nectar secretion in Mediterranean plants? New Phytologist., 133: 513-518.

60. Petretto, G.L., Tuberoso, C.I.G., Fenu, M.A., Rourke, J.P., Belhaj, O., Pintore G. (2017): Antioxidant activity, color chromaticity coordinates, and chemical characterization of monofloral honeys from Morocco. INT J FOOD PROP., 20: 2016-2027.

61. Rather, R.N., Wani, A.A., Kashtwari,M., Beigh, Z.A. (2018): Phenological shifts due to climate change and the associated conservation threats. Climate Change., 4(13): 80-86.

62. Rawal, D. S., Kasel, S., Keatley, M. R., Nitschke, C. R. (2014): Herbarium records identify sensitivity of flowering phenology of eucalypts to climate: Implications for species response to climate change. Austral Ecol., 40 : 117-125. doi:10.1111/aec.12183

63. Reille, M. (1992) : Pollen et spores d'Europe et d'Afrique du nord, Laboratoire de botanique historique et palynologie, Marseille, France. 520 p.

64. Roubik, D.W. and Buchmann, S.L. (1984): Nectar selection by Melipona and Apis mellifera (Hymenoptera: Apidae) and the ecology of nectar intake by bee colonies in a tropical forest. Oecologia., 61: 1-10.

65. Rumpff, L., Coates, F., Morgan J.W. (2010): Biological indicators of climate change: evidence from long-term flowering records of plants along the Victorian coast, Australia. Aust. J. Bot., 58: 428-439. https://doi.org/10.1071/BT10053

66. Sierra, A., Gómez, P.A., Gonell Galindo J. (1987) : Composición, propiedades físico-químicas y espectro polínico de algunas mieles monoflorales de España. Alimentaria., 185: 61-84.

67. St. John, L. and Tilley D. (2014): Plant Guide for Leafy spurge (Euphorbia esula). USDA-Natural Resources Conservation Service, Plant Materials Center. Aberdeen, Idaho, 83210. 4p.

68. Terrab, A., Berjano, R., Sanchez, J. A., Pajuelo, A.G., Díez, M.J. (2019): Palynological and geographical characterisation of Spanish oak honeydew honeys. Grana., 58: 63-77. DOI: 10.1080/00173134.2018.1509124

69. Terrab, A., Marconi, A., Bettar, I., Msanda, F., DÍEZ M.J. (2014): Palynological Characterization of Euphorbia Honeys from Morocco, Palynology., 38: 138-146.

70. Valdés, B., Díez, M.J., Fernández, I., Barneto, C. (1987): Atlas polínico de Andalucía occidental. Instituto de Desarrollo Regional 43, Universidad de Sevilla Excma. Diputación de Cádiz., 450 p

71. Waller, G. D. (1972): Evaluating responses of honey bees to sugar solutions using an artificial flower feeder. Ann. entom. Soc. Am., 65: 857-862.

72. White, F. (1983): The Vegetation of Africa: A Descriptive Memoir to Accompany the UNESCO/AETFAT/UNSO Vegetation Map of Africa. UNESCO, Paris. p. 228. 